\title{
Spatial Prioritization of Cost-Efficient Habitat

\author{
Protection for Species at Risk in Ontario
}

by

\author{
Caitlyn A. Proctor
}

A thesis submitted to the Faculty of Graduate and Postdoctoral

Affairs in partial fulfillment of the requirements for the degree of

Master of Science

in

Biology

Carleton University

Ottawa, Ontario

(C) 2021, Caitlyn A. Proctor 


\begin{abstract}
Conservation budgets are limited, so it is important to prioritize actions to efficiently protect species. Proxies for cost are frequently used as estimates for inclusion in prioritization problems to make more effective decisions. In this research, we combine real-world cost data for private land and species habitat models into a spatial prioritization problem to explore cost-efficient habitat protection possibilities for species at risk in Ontario. Our findings suggest that protecting species at risk through land purchase may be most cost efficient in areas where species-at-risk richness is relatively high and population density is low, such as in central Ontario. However, the budget required to adequately protect species at risk through land purchase is much larger than is currently available for conservation efforts. Therefore, to effectively protect species at risk in Ontario, we recommend the use of alternative conservation measures, such as easements on private land, to supplement already protected areas.
\end{abstract}




\section{Acknowledgements}

First and foremost, I would like to express my gratitude to my supervisor Dr. Joe Bennett for taking me on as a student and for providing me the opportunity to work on a project specifically suited to my research interests. Thank you for your continued enthusiasm and much needed encouragement, but also for allowing me to grow as a researcher.

Thank you to Dr. Richard Schuster who has always been quick to support me in my coding endeavors and has helped shape this project into how it stands today. I would also like to extend my appreciation to Dr. Rachel Buxton for encouraging me along the way and for providing guidance right up to the finish line.

A sincere thank you to the members of my advisory committee, Dr. Lenore Fahrig and Dr. Jeremy Kerr, for their insight along the way.

Andrew, thank you for always supporting me, both emotionally and with caffeine, listening to me work through problems, and for always having confidence in me. Finally, I would like to thank my parents for without lunchtime chats over coffee and consistent grammar-related phone calls I may not have managed to get to this point. Most of all, I would like to thank them for their never-ending love and encouragement. 


\section{Table of Contents}

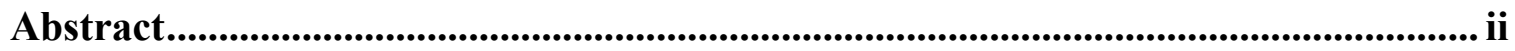

Acknowledgements ..........................................................................................................ii

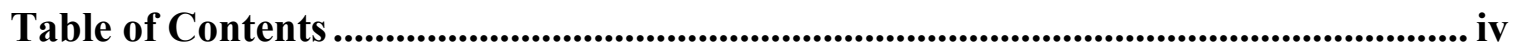

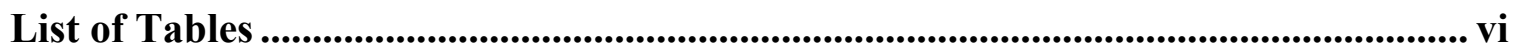

List of Figures........................................................................................................................ vii

List of Appendices........................................................................................................... viii

Chapter 1: Introduction ............................................................................................................. 9

\section{Chapter 2: A Spatial Prioritization Problem to Explore Cost-Efficient Habitat}

Protection Possibilities for Species at Risk in Ontario ................................................... 17

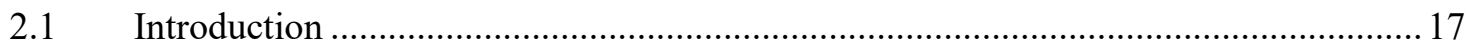

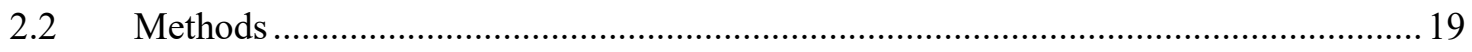

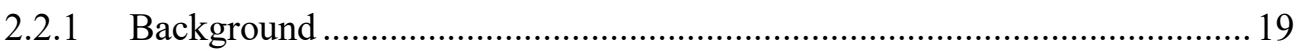

2.2.2 Project Approach........................................................................................ 21

2.2.3 Identifying Habitats of Species at Risk ......................................................21

2.2.4 Predicting Property Acquisition Cost.............................................................23

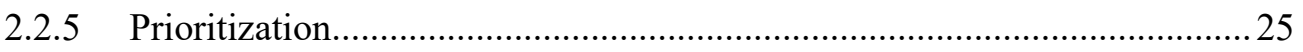

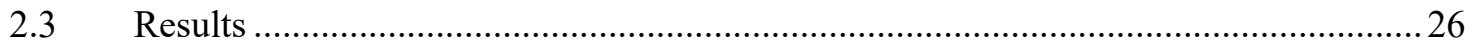

2.3.1 Identifying Habitats of Protected Species at Risk .......................................26

2.3.2 Prioritization.................................................................................... 29

2.3.3 Predicting Property Acquisition Cost..............................................................31

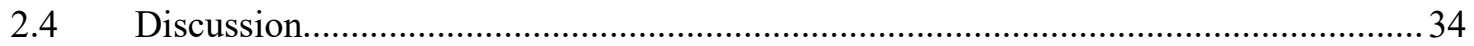

2.4.1 Identifying Habitats of Protected Species at Risk ……………………….......34

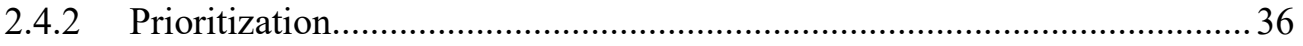

2.4.3 Predicting Property Acquisition Cost........................................................... 37 


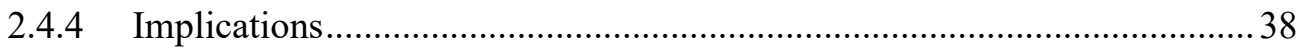

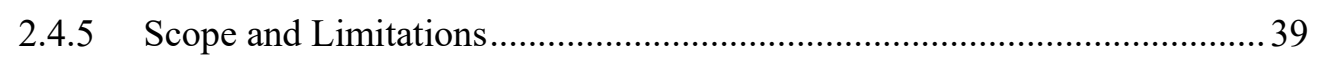

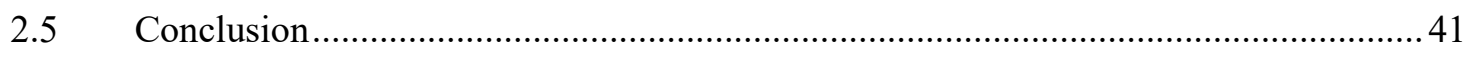

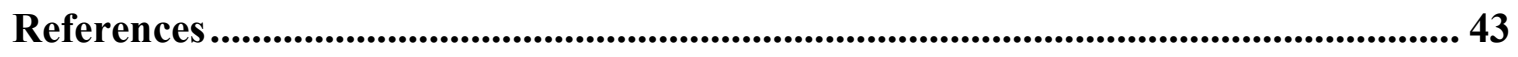

Appendix A: Supplemental Tables................................................................... 51

Appendix B: Supplemental Figures ........................................................................68

Appendix C: Model Summary ...................................................................................... 69 


\section{List of Tables}

Table 1. Protected areas and their managing parties in Ontario.................................. 22

Table 2. Total price, area, and number of parcels prioritized in each protection scenario

Table A1. Species and their threat level listed on the Species at Risk in Ontario List (SARO, 2018) with habitat requirements and range information source.

Table A2. Percent protected habitat and percent habitat on Crown land for each species on the Species at Risk in Ontario List...........................................63

Table A3. Total price, area, and number of parcels prioritized in each protection scenario

Table A4. Estimated land cost, total population, and population density from 2011

census for each census division 


\section{List of Figures}

Figure 1. Protected areas and unprotected Crown land in Ontario with heat map

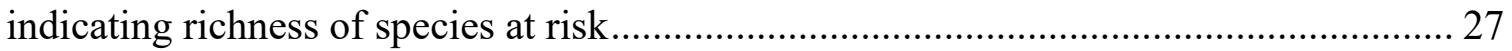

Figure 2. Distribution of percent protected habitat for species at risk in Ontario $(\mathrm{n}=175)$

Figure 3. Distribution of percent habitat on Crown land for species at risk in Ontario $(\mathrm{n}=175)$

Figure 4. Total cost of purchasing a percent habitat for each species at risk with the amount of Crown parcels included to reach a given percent habitat. 30

Figure 5. Areas prioritized for protection of 30\% habitat for each species at risk in

Ontario

Figure 6. Average land cost per hectare (bubble size) with a) species at risk richness and

b) population density per square kilometer (2011) in Ontario 33

Figure B1. Northern census divisions and population centers (Statistics Canada, 2016) in

Ontario .68 


\section{List of Appendices}

Appendix A: Supplemental Tables..................................................................... 52

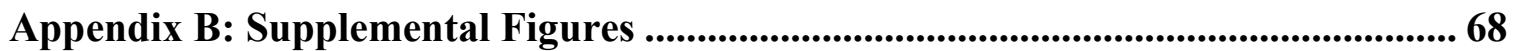

Appendix C: Model Summary ............................................................................................69 


\section{Chapter 1: Introduction}

Current extinction rates are significantly higher than natural background levels, and the rates continue to increase every year (Pimm et al., 2014; Kerr \& Deguise, 2004). This is true even for countries like Canada that still have vast areas of relatively intact ecosystems (Kerr \& Deguise, 2004). In Canada, common threats to species include, but are not limited to, development, human disturbance, climate change, and invasive species (McCune et al., 2013). It is suggested that conversion of natural areas to agricultural and urban land is responsible for most of the species decline in Canada (Venter et al., 2006; Kerr \& Cihlar, 2004).

With the goal of better protecting species and promoting the recovery of species at risk of extinction, Canada enacted endangered species legislation, the Species at Risk Act (SARA), in 2002 (SARA, 2021). In Canada, when a species is suspected to be at risk of extinction, an assessment of its status is conducted by the Committee on the Status of Endangered Wildlife in Canada (COSEWIC), which takes into consideration all relevant scientific and Aboriginal Traditional Knowledge to determine the species level of risk (COSEWIC, 2015). When the assessment is completed, COSEWIC provides a recommended listing status to the federal government, which then incorporates socioeconomic considerations and decides whether to list the species on the SARA registry. If a species is listed as endangered or threatened, it and its habitat are automatically protected from harm on federal land ( Creighton \& Bennett, 2019; Mooers et al., 2010).

Federal, provincial, and territorial governments share responsibility for protecting species at risk (SAR) in Canada. The protection afforded by SARA only applies on federal land, leaving the protection of species outside of federal land largely up to the 
provinces (Mooers et al., 2010). Six of the 10 provinces and one of the three territories have their own species at risk laws (Bergman et al., 2020; Olive, 2014). Ontario passed its own legislation, the Endangered Species Act (ESA), in 2007 (Endangered Species Act, 2007). The Act gave automatic protection to species at risk and their habitat on public and private lands and was considered to be the strongest provincial legislation in Canada (Olive \& Penton, 2018; Nixon et al., 2012). Similar to federal legislation, the Ontario ESA bases listing decisions on a scientific assessment of a species conducted by an independent group of experts, the Committee on the Status of Species at Risk in Ontario (COSSARO) (COSSARO, 2021). Although the initial legislation provided automatic protection to listed species and their habitats, it has since been weakened to delay protections (Bergman et al., 2020).

In 2010, as a response to the global biodiversity crisis, the United Nations Convention on Biological Diversity (CBD) established 20 objectives, known as the Aichi Targets, with a goal of slowing the decline of biodiversity by 2020 (CBD, 2010). Shortly after, Canada's federal, provincial, and territorial governments released the 2020 Biodiversity Goals and Targets for Canada (ECCC, 2016a). One objective of both the Aichi and Canadian targets, states that by 2020 at least $17 \%$ of terrestrial and inland water areas must be conserved using protected areas or "other effective area-based conservation measures" (OECMs) (ECCC, 2016a; CBD, 2010). The Aichi target states that OECMs should be well managed, connected systems that are also ecologically representative, a clause notably missing from the Canadian targets (Lemieux et al., 2019; CBD, 2010). At the end of 2019, Canada's official proportion of conserved terrestrial area was $12.1 \%$, including $11.4 \%$ in protected areas (ECCC, 2020). Though Canada did 
not reach its 2020 goals, a new area-based conservation plan has been released, stating that $25 \%$ of terrestrial and inland water areas should be conserved by 2025 , working toward $30 \%$ by 2030 (Trudeau, 2019).

Though well-intentioned, these quantitative, deadline-based targets are often debated in the conservation community and can lead to poor conservation outcomes. Frequently, quantitative area-based conservation targets are politically driven and not based on biological evidence; they are often referred to as inadequate and arbitrary (Svancara et al., 2005). The scientific community has long asked the question 'how much is enough' to conserve biodiversity. There seems to be a broad consensus that to protect current levels of biodiversity, the target for conservation of land should be much higher than it is, and this thinking has led to the 'Nature Needs Half' movement and the 'HalfEarth' project (Dinerstein et al., 2017; Locke, 2014). The exact percentage of land that should be protected has been debated. Some believe as little as $25 \%$ is sufficient, while others think as much as $75 \%$ of regions should be protected (Coristine et al., 2018). Furthermore, by putting deadlines on these quantitative targets, some jurisdictions dedicate their resources to simply increasing the quantity of protected areas by a certain date, instead of considering the quality or biological relevance of the land that should be protected (Lemieux et al., 2019). Although Canada's more recent target of 30\% protection by 2030 has improved from previous targets (17\% protected by 2020$)$ (ECCC, 2016a), decisions about adding to the protected area network should include consideration of a host of biological factors, rather than political ones. Failure to protect enough of the appropriate land will further threaten future biodiversity. 
The number of protected areas in Canada has been growing significantly over the past few decades, making 'protected area' the third largest land designation in the country, behind agriculture and forest (Lemieux et al., 2011). However, conservation planning has historically not been systematic, resulting in areas designated for conservation that do not adequately represent biodiversity (Andrew et al., 2011). At one point, reserve networks in Canada included no more endangered species than what would be expected by chance (Deguise \& Kerr, 2006).

Systematic conservation planning (SCP) is a structured approach to conservation that combines scientific information with social and economic factors to efficiently design and effectively implement conservation goals (Margules \& Pressey, 2000). Fundamentally, SCP can be broken down into six steps: identifying the conservation goal, collecting data across the planning area (both biological and socio-economic), assessing existing conservation areas, identifying areas for expansion of the conservation area, implementing, and finally, maintaining and monitoring (Margules \& Pressey, 2000). $\mathrm{SCP}$ is most often used for planning new protected areas but is also used for restoration activities and management. This method of planning especially excels at using resources efficiently and is known for its defensible decision-making process (Margules \& Pressey, 2000).

Systematic conservation planning can also be used for spatial conservation prioritization, which uses spatial analyses to identify locations for conservation investment (Kukkala \& Moilanen, 2013; Wilson, Cabeza, et al., 2009). Spatial conservation prioritization is similar to classic optimization problems in mathematics, with shared key features including the objective function or goal, state and control 
variables, and constraints (Wilson, Carwardine, et al., 2009). State variables symbolize the asset, or the item of conservation interest (e.g., habitat, populations). The control variables are the actions that can be taken that affect the asset (e.g., allocate money or resources). Constraints influence or limit the control variables and will determine whether the problem at hand is a maximal-coverage or minimal-coverage problem. A maximalcoverage conservation problem is one that aims to maximize conservation action without exceeding a constraint, for example, how much habitat can we conserve given a predetermined budget. A minimal-coverage conservation problem is one where the constraint is the minimum required conservation action achieved for each asset, for example, conserving at least a certain amount of habitat for a species (Wilson, Carwardine, et al., 2009). Often, conservation problems are complex and have multiple stakeholders, creating multiple objectives that can be combined into a single objective through weighted sums (Arponen, 2012).

As stated previously, a key component in systematic planning is efficiency, which in terms of spatial prioritization often means incorporating cost (Kukkala \& Moilanen, 2013; Wilson, Cabeza, et al., 2009; Naidoo et al., 2006). Integrating cost into spatial prioritizations is important because cost is not spatially homogeneous across a landscape and can be influenced by things like human population density or resource potential of the land (Naidoo et al., 2006). Costs associated with conservation can include opportunity (equal to what could have been gained by other potential land uses), acquisition (land purchase), management (costs associated with conservation programs), transaction (costs associated with exchange of resources), and damage (associated with economic damage from conservation activities) (Naidoo et al., 2006). 
Costs can be incorporated into conservation planning in several ways. One of the most common methods is a cost-benefit analysis, where there is a direct comparison between the cost of conservation and the resulting benefits. However, this method requires monetary values to be placed on biodiversity, which is arbitrary and ignores the intrinsic value of biodiversity (Naidoo et al., 2006). A common method used in conservation planning is the cost-effectiveness approach. Cost-effectiveness problems are different because they keep the benefits in the initial or given units (i.e., area, number of individuals, or species; Naidoo et al., 2006). Biologists frequently use non-monetary proxies for costs in conservation planning for ease, but also due to lack of accessible cost data (Wilson, Cabeza, et al., 2009; Balmford et al., 2003). Occasionally, factors that contribute to land costs, such as forest cover or human population density, are used in a weighted sum to estimate the purchase cost of land. However, these weighted sums can be subjective, making cost models based on actual economic data potentially the most accurate (Naidoo et al., 2006). By acknowledging the spatial variability of costs and integrating it with biological factors in prioritization problems, we can reach conservation goals more efficiently (Arponen et al., 2010; Naidoo et al., 2006), with a greater chance of implementation success (Kukkala \& Moilanen, 2013).

Spatial prioritization problems can help to identify areas for conservation investment, which may include more than strictly protected areas. The CBD Aichi Targets and the 2020 Biodiversity Goals and Targets for Canada mention the use of OECMs, in addition to strictly protected areas to help reach conservation targets (ECCC, 2016a; CBD, 2010). Though initially vague, in 2018, the CBD created guidelines for OECMs to properly define the concept and clarify misconceptions. An OECM was 
defined as "a geographically defined space, not recognized as a protected area, which is governed and managed over the long-term in ways that deliver the effective in-situ conservation of biodiversity, with associated ecosystem services and cultural and spiritual values" (CBD, 2018). These areas can be loosely categorized into three groups: areas with primary conservation objectives but the governing body of the land does not wish for the land to be a protected area, managed areas where conservation is a secondary outcome, and land where conservation objectives are not considered but are a by-product of management activities (Jonas et al., 2017).

These OECMs can be particularly useful for conservation in human-dominated landscapes where the majority of land is privately owned and land acquisition prices are high (Schuster et al., 2017). Commonly used OECMs on private land are conservation easements, which are voluntary agreements between landowners and land trusts or government agencies (Rissman et al., 2007). The easement holder, the land trust or government agency, restricts land use on privately owned land in return for payment or tax reductions to the landowner. Conservation easements are often created with the goal of reducing development and enhancing protection; however, not all easements are created equal. Easements can range from restricting all land uses, effectively creating a protected area, to allowing extensive land uses (Rissman et al., 2007). Nevertheless, conservation easements are still considered one of the most effective conservation strategies on private lands (Schuster et al., 2017). Typically, conservation easements restrict some land uses and require conservation actions to be applied for the duration of the agreement (Schuster et al., 2017). Provincial conservation programs, such as the Ontario Conservation Land Tax Incentive Program, exist to fund conservation easements. 
This particular program offers full property tax exemption for provincially significant areas of natural and scientific interest, provincially significant wetlands, habitats of endangered species, and community conservation lands (OMNRF, 2019a).

In this thesis, we will integrate real-world cost data into a spatial prioritization problem to analyze area-based SAR protection possibilities in Ontario. The prioritization analysis will seek to minimize the cost of protecting the greatest amount of habitat for SAR in Ontario. More specifically, we will determine how much it will cost to protect increasing proportions of habitat for each SAR and to identify priority areas for protection. By conducting a prioritization problem with realistic cost data, we can provide realistic cost-effective conservation strategies that will allow for more effective efforts, specifically in areas where high opportunity costs make land purchase less feasible. 


\section{Chapter 2: A Spatial Prioritization Problem to Explore Cost-Efficient Habitat Protection Possibilities for Species at Risk in Ontario}

\subsection{Introduction}

Globally, species face increasing pressures from land use change, human disturbance, climate change, and invasive species (Maxwell et al., 2016), which has resulted in the number of species at risk of extinction far exceeding natural levels (Pimm et al., 2014; Kerr \& Deguise, 2004). Canada is no exception when it comes to the state of biodiversity, with over 700 species listed as at risk of extinction (SARA, 2021). Ontario is of specific interest for species at risk (SAR) protection, as it is Canada's most-populous province and is highly biodiverse, compared to much of the rest of Canada (Olive \& Penton, 2018). In Ontario, over 200 species are considered at risk (SARO, 2018). There is a need to identify areas that should be prioritized for protection of these species and how to do so cost effectively.

To reduce extinction rates, it is critical that species are offered protection from human disturbances (Coristine et al., 2018; Myers et al., 2000). In recognition of this need and in response to the growing biodiversity crisis, national and international targets have been established, with the goal of protecting more land (ECCC, 2016a; CBD, 2010). Canadian targets aim to have $25 \%$ of land protected by 2025 (Trudeau, 2019). Currently, just over $12 \%$ of Canadian land is protected (ECCC, 2020). Ontario is in a similar state, with only $10 \%$ of land protected (ECCC, 2020). However, these existing protected areas have not necessarily been established in areas that offer the greatest protection for endangered species (Andrew et al., 2011; Deguise \& Kerr, 2006; Margules \& Pressey, 2000). 
Southern Ontario presents a unique challenge for protected area planning. It is the most developed area of the province and contains some of the highest-quality farmland in Ontario (OMECP, 2019b), resulting in high opportunity costs for conservation (Naidoo \& Adamowicz, 2006). However, it is also an important area for habitat protection because over $80 \%$ of Ontario's SAR are found in the southern portion of the province (OMECP, 2019b). Currently, less than 1\% of southern Ontario is protected (OMECP, 2019b); therefore, it is crucial for species' survival that more protection is offered.

To increase the amount of protected land in Ontario and to ensure the long-term survival of SAR, conservation plans and decisions need to be systematic (Arponen, 2012; Naidoo et al., 2006). Spatial prioritization allows conservation planners to determine locations for conservation that can most effectively protect species given limited funds (Wilson, Cabeza, et al., 2009).

To ensure the greatest conservation benefits with the resources available, cost data are frequently integrated with spatial biological data in prioritization problems (Arponen, 2012; Murdoch et al., 2007; Naidoo et al., 2006). Cost, whether it be implementation, management, opportunity, or purchase cost, is an important and practical variable to include when setting conservation goals; when ignored, it often negatively impacts the successful implementation of conservation plans (Naidoo et al., 2006).

Here, we use a property cost model, built from real-world property cost data, combined with SAR habitat models, in a prioritization approach to determine the most effective areas to prioritize for protecting the most SAR in Ontario. The target for this minimal-coverage problem is that a certain percentage of habitat be protected for each SAR listed in Ontario at the least possible cost. For example, if 15\% of each SAR's 
habitat was to be protected through land purchase, what is the minimum cost? In our case, we use a range of targets from $5 \%$ to $100 \%$ habitat conservation to examine variation in protection costs. Using the results, we can also pinpoint the best areas for protection within a defined budget.

This project differs from many others of similar scale in that we use habitat models for SAR, rather than range maps, to offer more tailored prioritization solutions. We also use real-world property cost data, which is not widely accessible; typically, proxies are used in their place, leading to skewed estimates of cost-effectiveness. The specific objectives of this research are to: 1) estimate the total area of terrestrial SAR habitat already protected in Ontario, 2) estimate the total area of terrestrial SAR habitat on Crown land, 3) identify priority areas for protection based on the ability to protect habitat for all SAR, and 4) estimate the cost of land acquisition for protecting various percentages of SAR habitat.

\subsection{Methods}

\subsubsection{Background}

Ontario is the second largest province in Canada. It covers over 1.1 million $\mathrm{km}^{2}$, and has over 25,000 species of plants and animals (Lemieux \& Scott, 2011). Currently, over 200 of those species are considered at risk in Ontario. Vascular plants and birds are the most at-risk groups in the province (SARO, 2018).

Southern Ontario, which is one of the most biologically diverse areas in Canada, has seen rapid urbanization and industrialization and is now the most densely populated region in Canada (Kraus \& Hebb, 2020). Consequently, there has been significant habitat 
loss in the area (Kraus \& Hebb, 2020), resulting in several unique and important habitats - including tallgrass prairies, savannahs, and alvars - becoming rare (Crins et al., 2009). Approximately $10 \%$ of the province is protected land, primarily under the jurisdiction of Ontario Parks (OMECP, 2021). The various agencies that oversee protected areas in Ontario include: two federal branches of government (Parks Canada and Environment and Climate Change Canada); Ontario Parks, under the Ontario Ministry of the Environment, Conservation and Parks; numerous municipal organizations; and non-governmental organizations, notably The Nature Conservancy of Canada (Lemieux \& Scott, 2011).

It is important to note that these agencies are given jurisdiction in certain areas based on whether the land is publicly or privately owned. In Canada, most of the land (89\%) is publicly owned (also called Crown land), which means that it is owned by either the federal (41\%) or provincial (48\%) governments (Olive, 2014). In Ontario specifically, Crown lands cover most of the province, especially in the north. The majority of the Crown land in Ontario (77\% of the province; OMNRF, 2020a) is managed under the Public Lands Act (OMNRF, 2020b), which can be used for natural resource extraction and is a source of revenue for the province. Another $10 \%$ of Ontario is Crown land classified as protected areas or conservation reserves (OMNRF, 2020a), and it is managed under the Provincial Parks and Conservation Reserves Act (OMECP, 2020). The remainder of the province is private land, primarily located in southern Ontario (OMNRF, 2021). Privately held land is owned by, for example, a non-governmental organization, a private individual, or a corporation. 


\subsubsection{Project Approach}

Prioritizing species' habitats involved a three-stage approach. First, we created habitat maps of SAR and identified the overlap of each species' habitat with already protected areas. Next, we built a model to estimate the acquisition cost of properties in Ontario using property and location variables. Finally, we ran prioritization scenarios with the goal of identifying properties to protect the most habitat for SAR in Ontario at the least cost.

\subsubsection{Identifying Habitats of Species at Risk}

Here, we focused on all terrestrial species listed as endangered, threatened, or special concern on "The Species at Risk in Ontario List" (Table A1 in Appendix A; SARO, 2018). To create habitat maps for each species $(n=175)$, we first recorded habitat requirements from assessment reports and recovery documents (Table A1 in Appendix A). We then paired the habitat requirements to land cover classes from the Ontario Land Cover Compilation V.2. (OMNRF, 2018b). This land cover layer consists of 29 land cover classes at a pixel resolution of $15 \mathrm{~m}$. Next, we selected the corresponding land cover classes from within each species' range to create habitat maps.

Many SAR range shapefiles were available in a single dataset (n=149; ECCC, 2016b). However, if a species was present on "The Species at Risk in Ontario List" but not included in the dataset from ECCC $(n=26)$, a range was obtained from management or recovery documents (Table A1 in Appendix A for list of species range sources). We acknowledge that there are more precise habitat models available for some species, such as species-specific distribution models (e.g. Rosner-Katz et al., 2020; McCune, 2016), 
but we used habitat associations from recovery documents to ensure that habitat depictions had the same precision for all SAR in subsequent analysis.

To determine the extent of protection for these habitats, we compiled a network of all areas in Ontario that are currently protected. This network includes federal and provincial protected areas and private properties owned by non-governmental organizations for the purpose of protection (Table 1). We also chose to include Indigenous-managed land as protected because Indigenous lands have been found to contain equal or higher levels of biodiversity than protected areas, suggesting that these areas afford protection to species at risk (Schuster, Germain, et al., 2019). We note, however, that doing so does not imply that Indigenous lands should be considered as part of protected area portfolios contributing to non-Indigenous governments' biodiversity commitments. The areas included in the protected area network are in Table 1.

Table 1. Protected areas and their managing parties in Ontario

\begin{tabular}{|l|c|l|l|}
\hline Layer & No. of Areas & \multicolumn{1}{|c|}{ Area Types } & \multicolumn{1}{|c|}{ Managing Party } \\
\hline $\begin{array}{l}\text { Federal Protected } \\
\text { Areas (OMNRF, } \\
\text { 2018a) }\end{array}$ & 34 & $\begin{array}{l}\text { National park, national } \\
\text { wildlife area, other federal } \\
\text { protected area }\end{array}$ & $\begin{array}{l}\text { Parks Canada, } \\
\text { Environment and } \\
\text { Climate Change } \\
\text { Canada }\end{array}$ \\
\hline $\begin{array}{l}\text { Federal Lands (Other) } \\
\text { (OMNRF, 2019c) }\end{array}$ & 1951 & $\begin{array}{l}\text { Canal, community, military } \\
\text { base, settlement, tower, } \\
\text { other }\end{array}$ & Federal Government \\
\hline $\begin{array}{l}\text { Indigenous Lands } \\
\text { (Natural Resource } \\
\text { Canada, 2017) }\end{array}$ & 424 & & First Nations \\
\hline $\begin{array}{l}\text { Provincial } \\
\text { Conservation Reserve } \\
\text { (OMNRF, 2019b) }\end{array}$ & 295 & $\begin{array}{l}\text { Regulated provincial parks, } \\
\text { protected areas under Far } \\
\text { North Act }\end{array}$ & \begin{tabular}{l} 
Ontario Parks - \\
OMNRF \\
\hline $\begin{array}{l}\text { Provincial Parks } \\
\text { (OMNRF, 2019e) }\end{array}$
\end{tabular}$\quad 343$ \\
\hline $\begin{array}{l}\text { Provincial Enhanced } \\
\text { Management Area } \\
\text { (OMNRF, 2012) }\end{array}$ & 8 & Great Lakes Coastal Area & OMNRF \\
\hline
\end{tabular}




\begin{tabular}{|l|c|l|l|}
\hline $\begin{array}{l}\text { NCC Properties } \\
\text { (Nature Conservancy } \\
\text { of Canada, 2018) }\end{array}$ & 250 & $\begin{array}{l}\text { Nature Conservancy } \\
\text { of Canada }\end{array}$ \\
\hline $\begin{array}{l}\text { NGO Nature Reserves } \\
\text { (OMNRF, 2019d) }\end{array}$ & 24 & $\begin{array}{l}\text { Private organizations } \\
\text { (e.g., Ducks } \\
\text { Unlimited) }\end{array}$ \\
\hline
\end{tabular}

Finally, to measure the overlap of each species' habitat with the complied protected area network, we converted the habitat shapefiles into raster files at $100 \mathrm{~m} \mathrm{x}$ $100 \mathrm{~m}$ resolution. We then calculated the number of raster cells of each species habitat that overlapped with the protected area network. The percentage of protected habitat was calculated for each species by dividing the number cells overlapping with a protected area by the total number of cells occupied by a species' inferred habitat.

As a complementary analysis, we conducted the same calculation to determine the percentage habitat that overlaps with Crown land that is not protected (i.e., not managed under the Provincial Parks and Conservation Reserves Act; for example general use area, natural heritage area, wilderness area) using the Ontario Crown Land Atlas dataset (OMNRF, 2012).

\subsubsection{Predicting Property Acquisition Cost}

To construct a model that estimates property cost, we collected cost data for 2150 rural properties across Ontario’s census divisions. We selected properties using a random point generator feature in ArcGIS (ESRI Inc., 2019), which ensured properties were at least $500 \mathrm{~m}$ from each other and therefore evenly dispersed through each census division. Fifty properties were identified in each of the 38 southernmost census divisions. However, only 25 properties were identified in each of the 10 northernmost census divisions (hereafter referred to as the northern region, including Algoma, Cochrane, Kenora, Manitoulin, Nipissing, Rainy River, Sudbury Greater, Sudbury, Thunder Bay, 
and Timiskaming; see Fig. B1 in Appendix B), because properties with available information were often clustered in small communities and did not meet the constraint of being at least $500 \mathrm{~m}$ apart. Population centers, which are defined as areas with a population density of at least 400 persons per square kilometer (Statistics Canada, 2016), were removed from the analysis because they would be less feasible for protection through land purchase (Fig. B1 in Appendix B). As a result, one census division (Toronto), was completely removed from the analysis. In summary, the criteria for including a property in the analysis were that it was at least $500 \mathrm{~m}$ from any other property already included in the analysis and that it was not located in a population center.

Using the GPS coordinates produced from the random point generator, we located the nearest property in Geowarehouse, a property information software package (TERANET, 2020). This software uses information from the Ontario Land Registry and the Municipal Property Assessment Corporation (MPAC) to report property details and price assessment information. This software operates on a cost-per-property view basis, so to manage project costs, a sample of 2150 properties was collected. For each of the 2150 properties, we collected data on the assessed property values in Canadian dollars (CAD) from 2016 (the most recent province-wide property assessment year), area in square meters, whether a property had farmland, forest, or water present based on the Ontario Land Cover Compilation V.2. (OMNRF, 2018b), and if any buildings were present on the property (OMNRF, 2017).

Finally, we constructed a log-linear model to predict property cost of private land using the following variables: property area in hectares as a continuous variable, property 
type given by the constructed dataset as a series of binary variables (i.e., farm, forest, water buildings), census division as a categorical variable, and property cost as a dependent variable. The model for property cost was as follows:

$$
\log (\text { price })=\log (\text { area })+\text { census division }+ \text { water }+ \text { forest }+ \text { farm }+ \text { building. } \quad 1 .
$$

\subsubsection{Prioritization}

We used prioritizr (Hanson et al., 2021) to build conservation prioritization scenarios with the goal of identifying priority areas for conservation that can protect certain percentages of habitat for all SAR in Ontario for the least cost. Prioritizr is an R package for building and solving systematic conservation planning problems that uses integer linear programming (ILP) (Hanson et al., 2021). ILP is often used in management decisions, specifically optimization problems where objectives are minimized/maximized based on linear constraints (in our case, minimum protection target for each species) and decisions are discrete (in our case, whether to prioritize a property for protection or not) (Beyer et al., 2016). Prioritizr uses an exact algorithm solver to ensure optimal solutions, in this case Gurobi 9.0.3 (Guribi Optimization, 2021).

We ran multiple protection scenarios ranging from $5 \%$ to $100 \%$ of habitat protected for all SAR in Ontario. Our problem objective was to minimize the cost of the solution, while our target was to ensure the given habitat percentage was met for all species. We chose to include an argument that ensured Crown land properties were selected in the solution. We added Crown land with zero cost to reflect what we feel is a realistic scenario: the government choosing to prioritize land that they already hold for protection, rather than purchasing private land. However, we note that our analysis accounts for private land costs only. We acknowledge that protecting Crown land comes 
with non-zero costs as well as opportunity costs, but we assume that these costs would be lower than purchasing private land. Finally, we set the decision function to be binary, so that the solution either prioritized whole properties or it did not.

\subsection{Results}

\subsubsection{Identifying Habitats of Protected Species at Risk}

Greater concentration of SAR habitat is found in the southern region Ontario (Fig. 1). Our analysis shows that the most commonly used habitat types by SAR in Southern Ontario include deciduous forest, agriculture, and tallgrass habitats, with up to 33 (19\%) SAR relying on those habitat types. The most commonly used habitat types in the northern region were mixed forest, coniferous and deciduous forests, which were home to up to $10(6 \%)$ SAR. The least commonly used habitat types, in both the southern and northern regions, were wetland habitat types (e.g., marsh, swamp, fen, bog, and heath).

Protected areas represent about $12 \%$ of the terrestrial area in Ontario, located mostly in the northern region of the province (Fig. 1). Only 4\% of protected areas (by area) are in the southern portion of the province. 


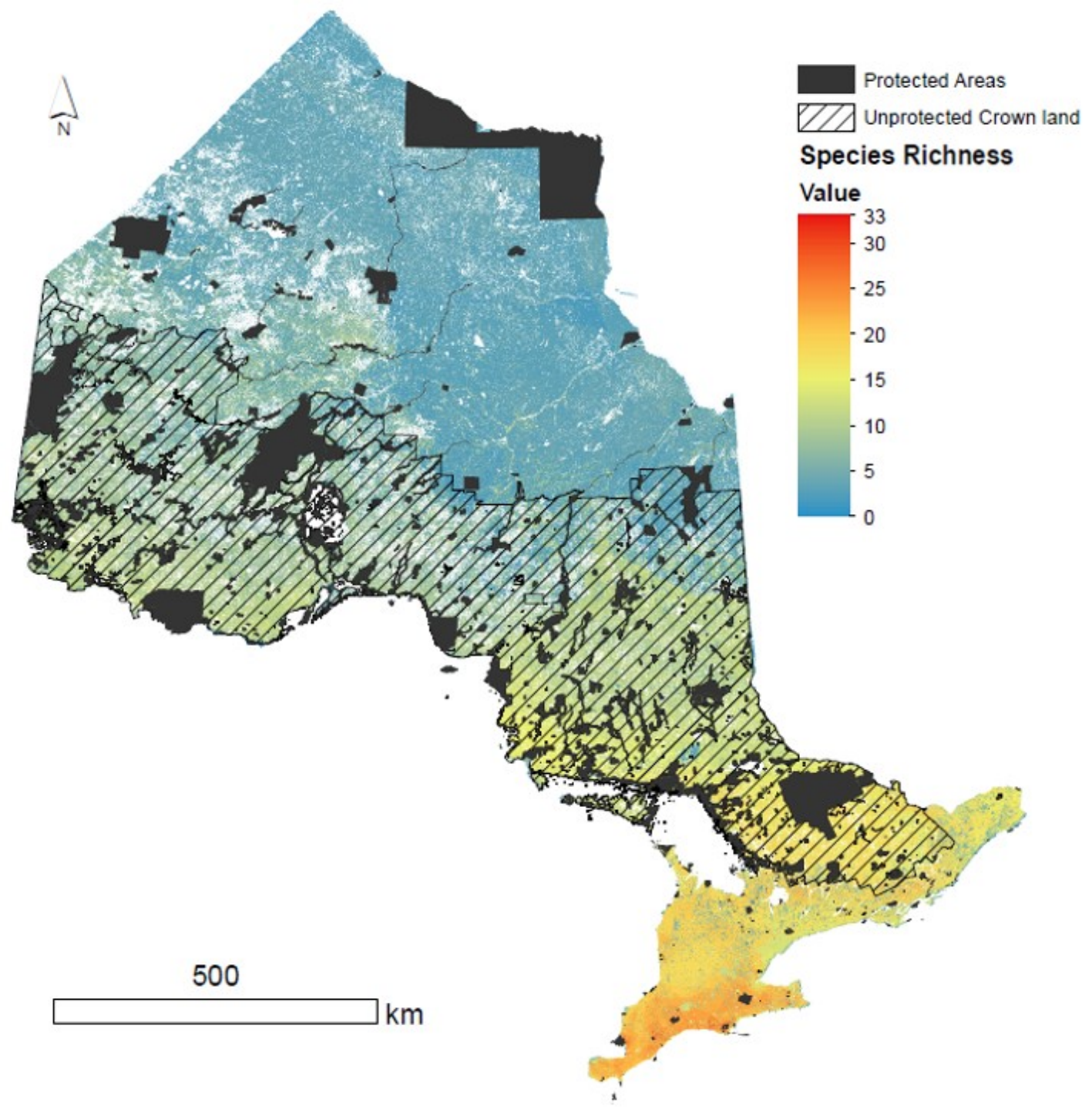

Figure 1. Protected areas and unprotected Crown land in Ontario with heat map indicating richness of species at risk

When assessing the overlap between existing protected areas and the habitats of 175 species at risk, we found that half $(\mathrm{n}=88)$ of all species at risk had less than $10 \%$ of their habitat protected by existing protected areas and most species ( $\mathrm{n}=133$ or $76 \%)$ had less than half of their habitat protected (Fig. 2). Six percent of species (n=11) had none of their habitat protected, which included eight plant species, one mollusk, one amphibian, 
and one insect (Table A2 in Appendix A). However, $8 \%$ of species $(n=14)$ had over $90 \%$ of their habitat protected, including two species, the lakeside daisy (Tetraneuris herbacea) and white prairie gentian (Gentiana alba), which exist completely within protected areas.

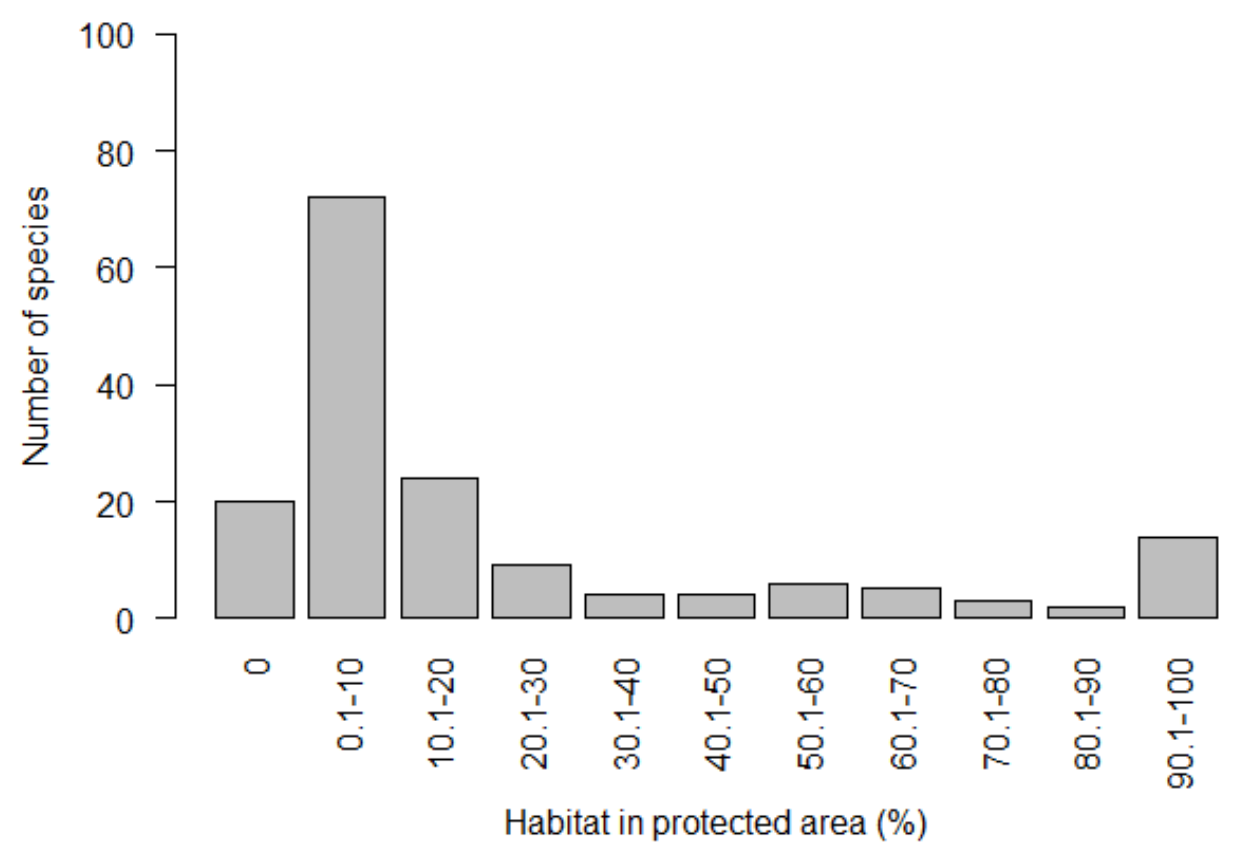

Figure 2. Distribution of percent protected habitat for species at risk in Ontario $(\mathbf{n}=\mathbf{1 7 5})$

Over one-third $(n=67)$ of the species' habitats did not overlap at all with Crown land and most of the species ( $\mathrm{n}=138$ or $78 \%$ ) had less than half of their habitat overlap with Crown land (Fig. 3). Fifteen percent of species $(n=26)$ had between $50 \%$ and $90 \%$ habitat overlapping with Crown land and no species' habitat overlapped Crown land by more than $90 \%$. 


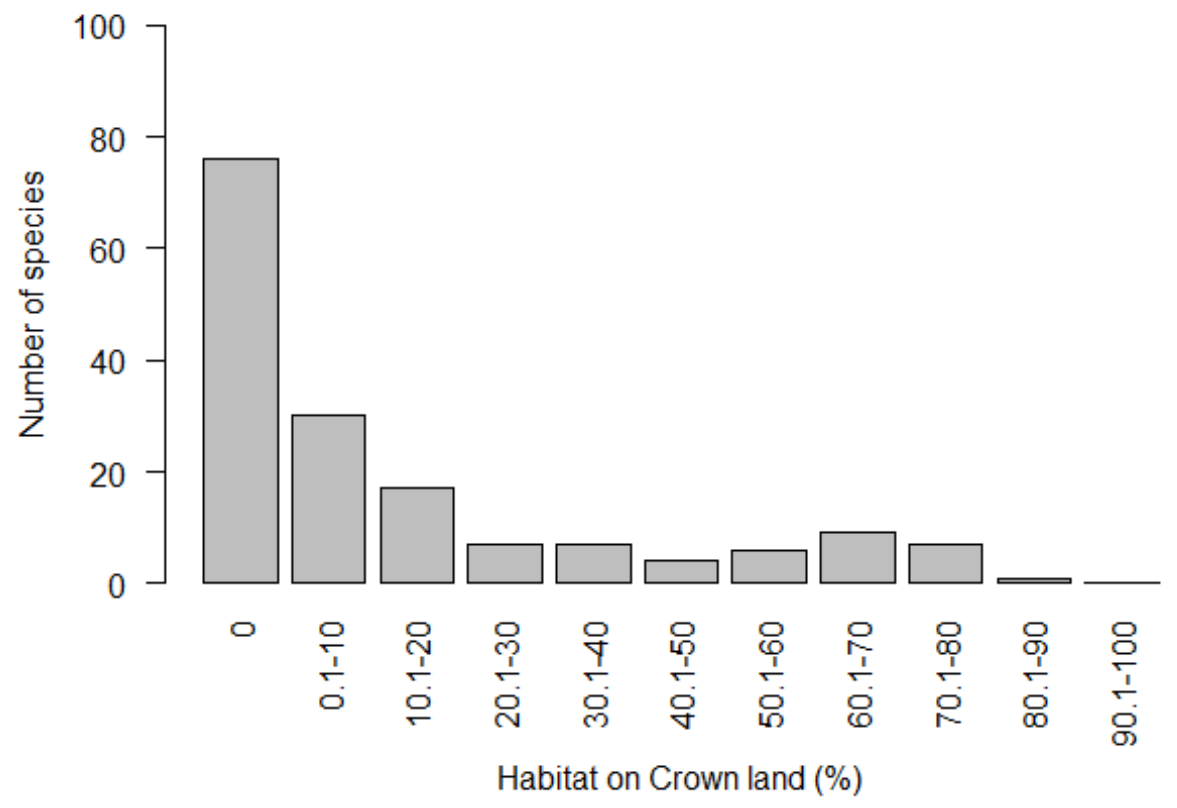

Figure 3. Distribution of percent habitat on Crown land for species at risk in Ontario (n=175)

\subsubsection{Prioritization}

The cost of protecting SAR habitat increases with greater percentages of habitat protected (Fig. 4; Table A3 in Appendix A). Figure 4 shows a habitat protection-cost curve for all species at risk in Ontario. The cost curve starts with a very shallow slope, indicating that at lower percentages of habitat protection there is a smaller cost increase for additional protection through land purchase. However, with higher percentages of habitat protection the slope progressively steepens, indicating a rapid increase in land acquisition cost. Correspondingly, the relative amount of Crown land parcels included in each protection scenario exhibits a decreasing trend (Fig. 4). 


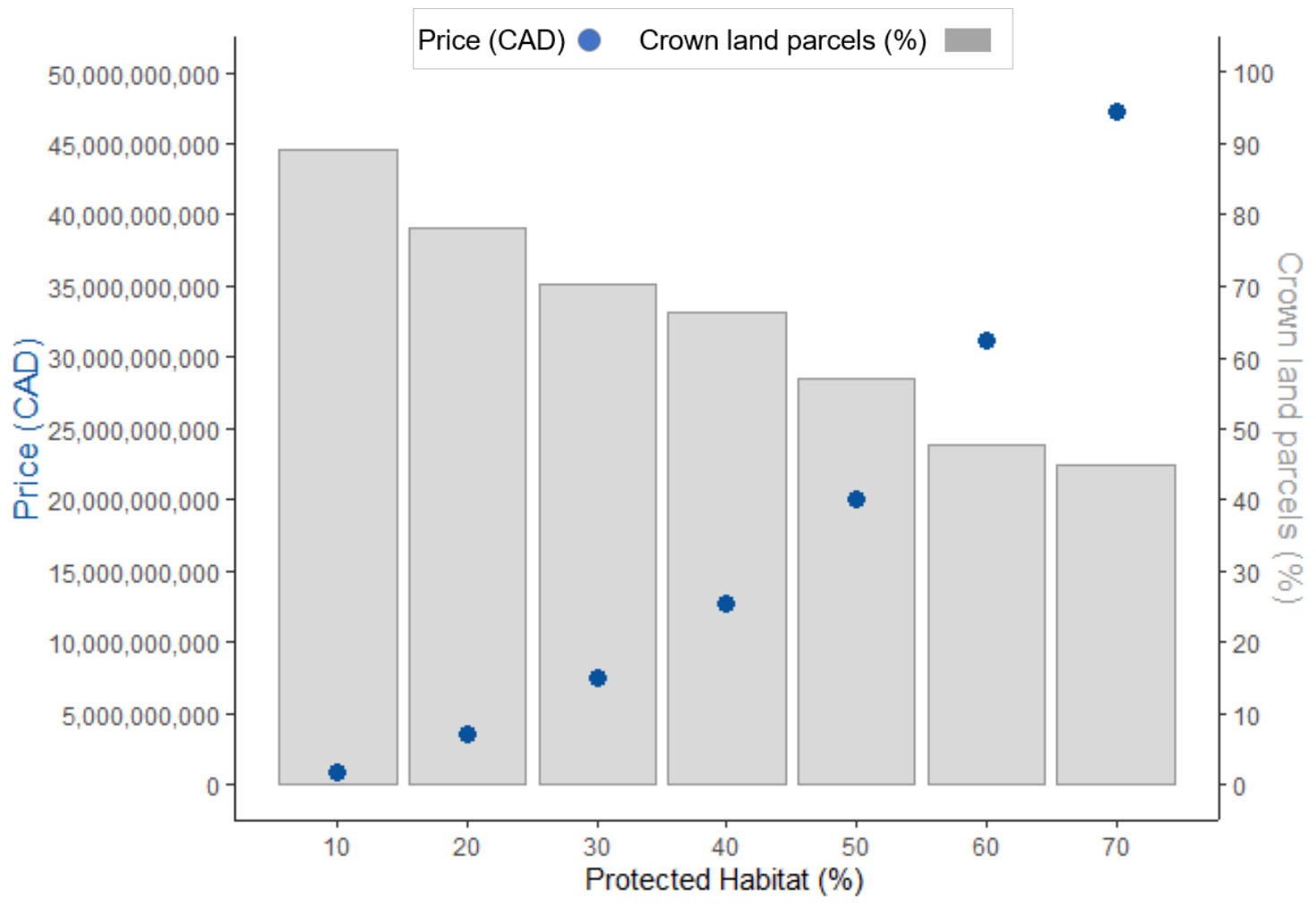

Figure 4. Total cost of purchasing a percent habitat for each species at risk with the amount of Crown parcels included to reach a given percent habitat. As an example, if we want to protect $30 \%$ of each species habitat, it would cost about $\$ 7.5$ billion and $70 \%$ of the parcels would be Crown land. Costs for increments from $70 \%$ to $100 \%$ can be found in Table A3 in Appendix A.

Figure 5 shows parcels that were the most cost-effective solution for protecting 30\% habitat (Canada's 2030 conservation target; Trudeau, 2019) for each species through land purchase. Central Ontario is the most densely prioritized region, whereas the southernmost region of the province has sparely selected properties. Noticeable areas that are not prioritized are the Ottawa region, the Algonquin park area, and the northern portion of the province. 


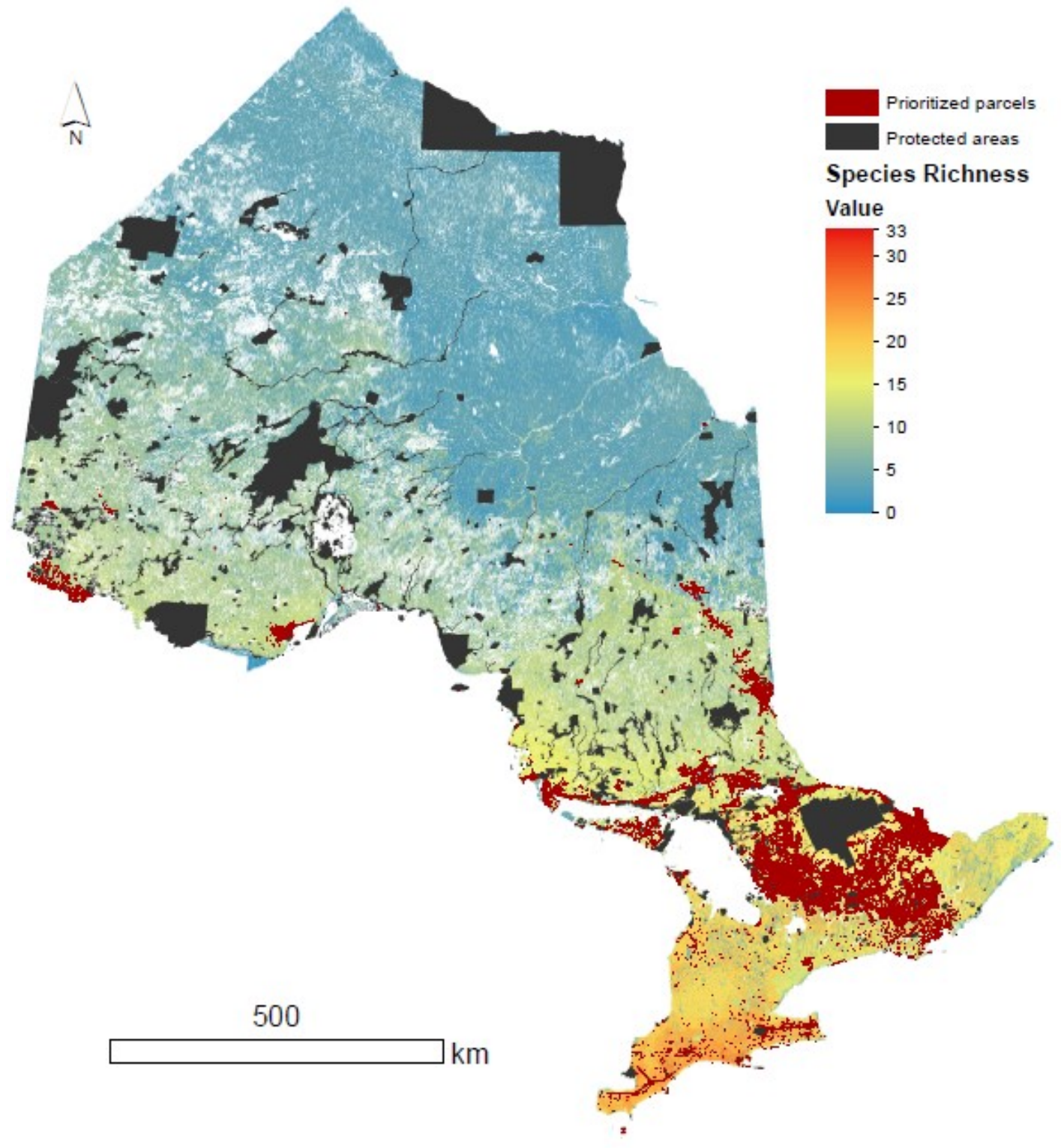

Figure 5. Areas prioritized for protection of $\mathbf{3 0 \%}$ habitat for each species at risk in Ontario

\subsubsection{Predicting Property Acquisition Cost}

The model we created proved to be a good predictor of property cost in Ontario $\left(\mathrm{R}^{2}=0.649, \mathrm{P}<0.001\right)$. Every predictor variable had a significant influence on the model (see Appendix C for model summary). 
Model estimates of average land cost per hectare were much higher in the more southern census divisions, specifically those with higher population density (Fig. 6; see Table A4 in Appendix A). The census division with the highest land cost per hectare was Peel, which is located directly to the west of Toronto, while the census division with the lowest land cost per hectare was Algoma, which is located north of Manitoulin Island. 


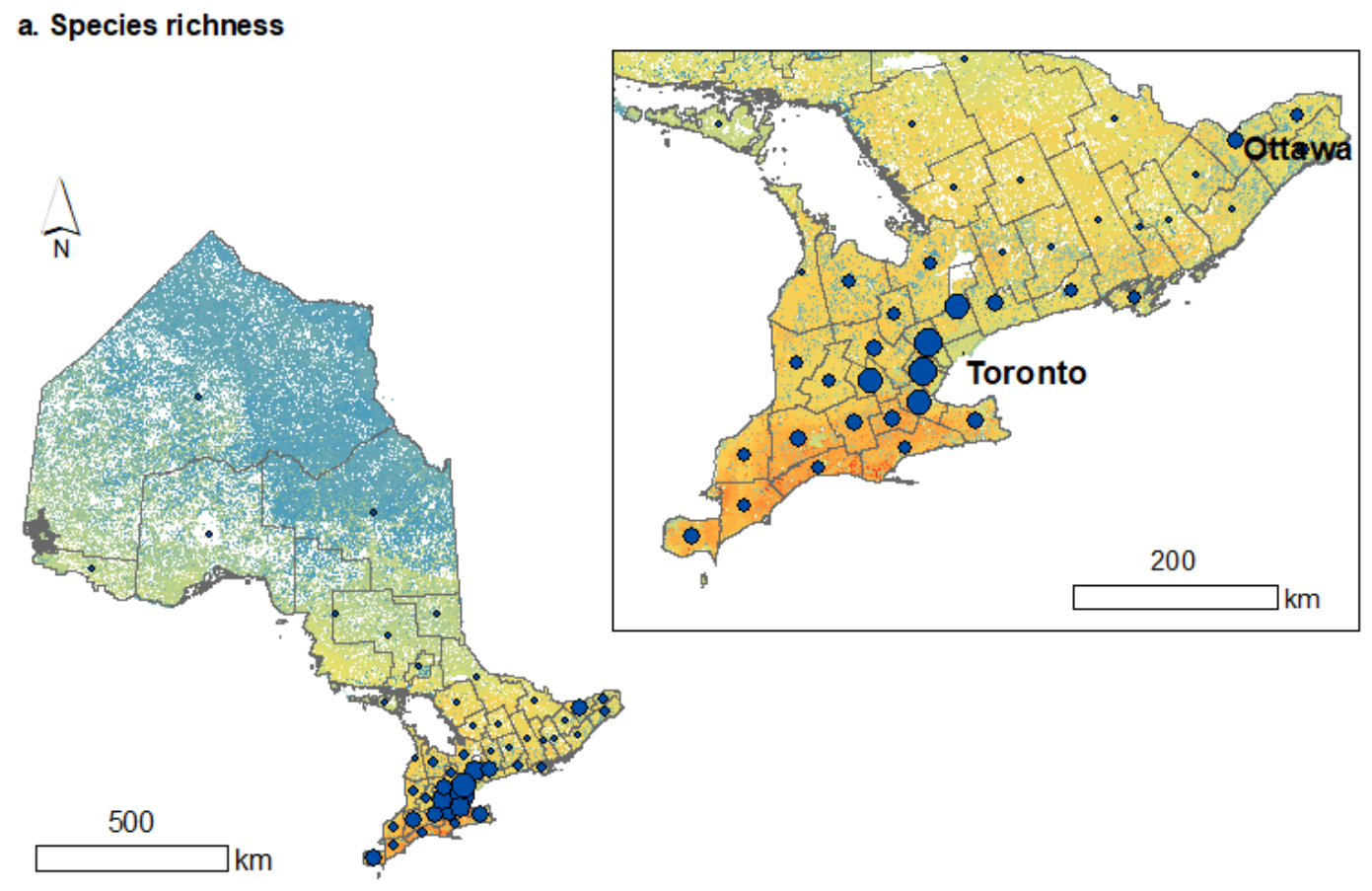

b. Population density

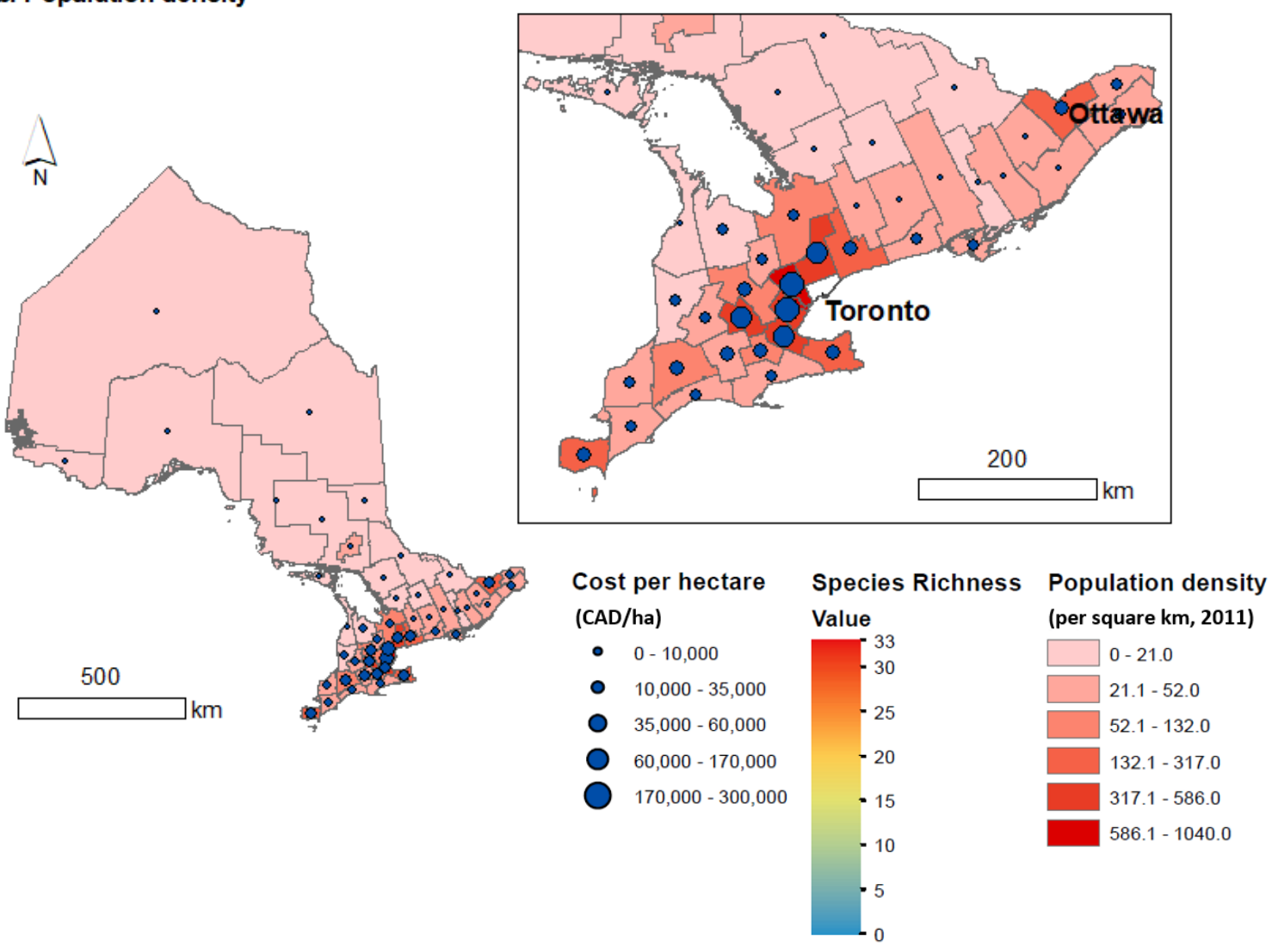

Figure 6. Average land cost per hectare (bubble size) with a) species at risk richness and b) population density per square kilometer (2011) in Ontario 


\subsection{Discussion}

In most cases, if cost is included in conservation prioritization problems, a proxy is used to estimate property cost. Typically, cost is equated with area (e.g. Schuster, Wilson, et al., 2019; Stewart \& Possingham, 2005). Here, we incorporate real-world cost data for private land into a spatial prioritization problem to explore habitat protection possibilities in Ontario. More specifically, we identify priority areas for protecting different amounts of habitats for SAR for a minimum cost to support practical and costeffective conservation planning. Further, we use habitat models for SAR, rather than range models, which provides a more tailored prioritization solution than many other projects of similar scale (e.g., Bolliger et al., 2020).

\subsubsection{Identifying Habitats of Protected Species at Risk}

Assessing the current state of protection for terrestrial SAR and their habitats in Ontario is important for evaluating the usefulness of the existing protected area network and for planning future protected areas when trying to meet conservation targets. Currently, Ontario's protected area network does not effectively offer protection for SAR and their habitats. Given that most SAR habitat is in the southern region of the province and the largest and most numerous protected areas are in the northern region, it is clear why the majority of SAR have less than half of their habitat protected (Fig. 1).

The inefficiency of existing protected areas in Ontario, and nationally, has been previously acknowledged, especially for SAR (Bolliger et al., 2020; Deguise \& Kerr, 2006). More recently, it was recognized by the Auditor General of Ontario that protected areas, specifically in southern Ontario, need to better protect SAR (Lysyk \& DeMarco, 2020). Areas with high biodiversity tend to overlap with areas of dense human population 
and are therefore more vulnerable to land conversion (Andrew et al., 2011; Cincotta et al., 2000). Additionally, protected areas tend to be established in less populated and less biodiverse areas (e.g., Arctic and boreal regions) like northern Ontario. These protected areas in less diverse regions also tend to be much larger than those in more biodiverse areas (Andrew et al., 2011; Deguise \& Kerr, 2006). This results in the most imperiled species and habitats, like in southern Ontario, receiving much less formal protection. When they are afforded protection, they are more likely to be affected by surrounding land use pressures and less likely to accommodate dispersal of species among habitats (Andrew et al., 2011).

In areas like southern Ontario with large populations and increasing land use, establishing new protected areas or expanding existing ones may be difficult (Arponen, 2012; Deguise \& Kerr, 2006). However, it is worth noting that the addition of smaller protected areas can provide protection for small populations of at-risk species and habitat remnants (Bennett \& Arcese, 2013; Andrew et al., 2011). This could be particularly useful for the remaining small patches of tallgrass habitats found in southern Ontario, which we found to be heavily relied upon by SAR. A good example of the utility of small protected areas is the Ojibway Prairie Provincial Nature Reserve in southern Ontario, which contains one of the largest remaining tallgrass prairie habitat patches in Ontario (Ontario Parks, 2002) and is relied upon by many SAR, such as slender bush clover (Lespedeza virginica; COSSARO, 2007).

Nevertheless, SAR in Ontario are not adequately protected by the current network and although the existing small protected areas may protect select small populations, they do not provide protection for the SAR that exist outside of those small areas. Therefore, 
in areas such as southern Ontario, the majority of SAR may have to rely upon alternative protection measures, such as OECMs.

\subsubsection{Prioritization}

When applying a cost-effectiveness problem to a land purchase prioritization for SAR in Ontario, the prioritization identified areas required to meet habitat targets for the lowest costs. For example, if aiming to protect $30 \%$ habitat for all SAR in Ontario, the prioritization suggests that most of the land purchase should occur in south-central Ontario, with scattered purchases in southern Ontario (Fig. 5). This example illustrates the balance that can be achieved through prioritization problems. If the prioritization were to target SAR habitats without considering cost, or if it were to consider area as a proxy for cost as is typical in some priority-setting exercises (e.g. Schuster, Wilson, et al., 2019; Stewart \& Possingham, 2005), it would recommend land purchase in areas with the highest species richness (i.e., southern Ontario). However, land purchase in that area is highly impractical due to high cost (Fig. 6). Additionally, if the prioritization were to only minimize cost to achieve an area-based target regardless of SAR habitat requirements, it would suggest land purchase in the northern region where land cost is lower, but it would not benefit many SAR. Therefore, to be as efficient as possible with conservation funds, land purchase for the protection of SAR would be most effective in areas where there is still a relatively high SAR richness, but human population density (and land cost) is also low, resulting in a lower purchase cost (Balmford et al., 2003).

When trying to achieve protection targets, the use of Crown land offers a viable strategy. Like existing protected areas, the majority of Crown land is located in the northern and central portions of Ontario, making the overlap with SAR habitat generally 
low (Fig. 1). When protecting smaller overall percentages of SAR's habitat, Crown land is a viable option for reaching protection targets at a lower cost. However, as habitat protection targets increase, it becomes increasingly necessary to include private land purchase, causing purchase costs to increase exponentially (Fig. 4).

\subsubsection{Predicting Property Acquisition Cost}

In establishing new protected areas, it is important to consider economic variables to create efficient conservation plans (Arponen, 2012; Wilson, Carwardine, et al., 2009; Naidoo et al., 2006). This is especially important because often when conservation targets are agreed upon, the cost associated with meeting those targets is unknown (McCarthy et al., 2012). Here, we used real-world cost data to build a model to estimate the cost to purchase properties in Ontario for SAR protection and found that properties in the southern region of the province, specifically those near dense human populations, were the most expensive. Purchase cost is more likely to be higher in areas that are valuable for uses other than conservation, specifically for development and agricultural use (Robillard \& Kerr, 2017) (where proximity to infrastructure and population is important (Balmford et al., 2003)). This explains the purchase cost pattern seen in southern Ontario, where population density is the highest, purchase cost is the highest (i.e., greater Toronto area and Ottawa) and where there are large areas of land suitable for agriculture, purchase cost is also high (Fig. 6). Although potential purchase cost proxies like population and opportunity cost may show similar patterns to that of our cost model, those variables remain somewhat subjective and do not achieve the accuracy that comes from using actual cost data (Wilson, Cabeza, et al., 2009; Naidoo et al., 2006). 
Although this prioritization problem aims to reach the conservation target for the least possible cost, it is clear that costs of habitat conservation beyond a low level such as 5\% would be substantial (Fig. 4 and Table A3 in Appendix A). The estimated cost for protection rapidly increases above $5 \%$, so when considering the recent protection targets of $30 \%$ by 2030 (Trudeau, 2019) - which would cost approximately $\$ 7.5$ billion protection through mechanisms other than strict protection, such as OECMs, should be explored to help achieve targets while being more cost effective.

\subsubsection{Implications}

Ontario has not significantly added to the protected area network in the last five years, and there is no long-term plan to expand the network in the future (Lysyk \& DeMarco, 2020). Furthermore, given the unrealistic costs associated with land purchase, especially in locations with the most SAR, exploring alternative protection measures on private lands will be necessary. Strictly protected areas can be supported by OECMs on private lands that offer refuge to species, but are not recognized as protected areas (Dudley et al., 2018). OECMs were first introduced in the CBD's Aichi target 11 as a complimentary approach to protected areas to conserve important biodiversity (Lemieux et al., 2019).

The most common approach to private land conservation is a voluntary conservation easement (Kamal et al., 2015). Conservation easements are legal agreements between private landowners and a non-profit land trust or government organizations in which landowners retain title but agree to certain conservation actions or land-use restrictions (Schuster et al., 2017; Kamal et al., 2015). In return, landowners are given incentives such as payments or tax reductions (Rissman et al., 2007). Easements 
have much lower initial costs compared to land acquisition (Schuster et al., 2017), which makes them well suited for limited budget scenarios. These agreements are especially effective for non-agricultural lands where financial compensation is less important (Drescher et al., 2017).

Conservation easements on private land can be particularly important in areas like southern Ontario, where our prioritization suggests that land acquisition is impractical and there is limited Crown land available. They can help fill protection gaps and increase connectivity for species whose ranges may be in areas with little or no protection (Rissman et al., 2007).

Although OECMs and easements are becoming increasingly important for achieving successful conservation (Drescher et al., 2017), they do have their challenges, including landowner's willingness to participate and compliance (Schuster et al., 2017). Easements are certainly not meant to replace strictly protected areas and should only be considered in specific circumstances where protected areas are impractical. Furthermore, OECMs are important for more than just meeting conservation targets, because even if those targets are reached, protected areas completely isolated from other natural areas by developed land will not provide long-term benefits to many species (Dudley et al., 2018).

\subsubsection{Scope and Limitations}

This study focuses on the spatial prioritization of SAR habitat in Ontario using a purchase cost model, which identifies the most cost-efficient areas to purchase to protect SAR. The scope of this study does not reach beyond the boundaries of Ontario and strictly focuses on species listed on the Species at Risk in Ontario List. Nonetheless, ideas presented here can be applied more widely, beyond Ontario. We acknowledge that there 
are costs associated with protected areas beyond purchase cost, such as land transfer, management, and potential restoration costs. However, this study focuses only on illustrating the approximate magnitude and heterogeneity of costs to purchase SAR habitat across Ontario.

We chose to use SAR habitat as our biological metric in the prioritization problem. Other metrics, such as genetic diversity (Ottewell et al., 2016) and endemism (Bode et al., 2008) have been used in similar studies. Although these alternative metrics are useful, we felt that by using a simpler variable (i.e., SAR richness), we were able to accomplish the goal of our study, which was to provide cost-effective protection scenarios for SAR. More importantly, SAR have certain legal protections in Ontario (Endangered Species Act, 2007), while other potential conservation goals, such as genetic diversity and endemism, do not.

Additionally, when constructing our own habitat models, we aimed to balance overestimating and underestimating species occurrences. By using species habitats rather than species ranges, we could have underestimated the occurrence of species because some species can occupy habitat types other than those listed in recovery documents. Furthermore, we could have overestimated species occurrences because species do not always fully occupy the available habitat. However, we believe that, when studying SAR, using a habitat model may be more appropriate than using range maps that may overestimate species occurrences (Jetz et al., 2008). We acknowledge that there may be more accurate species distribution data for some of the species used in this study (e.g., Rosner-Katz et al., 2020; McCune, 2019), but we are not aware of a dataset that provides more accurate information on all habitats of SAR in Ontario. 
When using economic data, it is also important to emphasize that costs will likely change over time. Specifically, purchase costs can be expected to increase over time (Robillard \& Kerr, 2017). This could affect the outcomes of the prioritization and underscores the importance of implementing conservation actions without delay. In addition, our prioritization assumes that property owners would be willing to sell their properties, which would not always be the case. Where sellers would be unwilling, then less cost-efficient properties would have to be chosen, likely driving up actual costs.

In addition, this study does not consider current or future threats to SAR and how they may affect their protection in the future. Further spatial prioritization studies for SAR in Ontario should consider how species ranges may shift due to climate change, which would require species distribution models for all SAR. Another variable to consider in potential prioritizations is land use changes and how those changes may affect future habitat loss. Including either climate change or land use change or both in a spatial prioritization, similar to the one conducted here, would require more extensive data analysis and likely more factors, such as connectivity, but would also reflect the future needs of species for conservation planning.

\subsection{Conclusion}

Given that conservation budgets are constrained, it is important to determine the most cost-efficient strategies to protect SAR (Naidoo et al., 2006; Margules \& Pressey, 2000). Our prioritizations suggest that when considering land purchase for the protection of SAR in Ontario, it may be most cost-efficient to purchase land in areas like central Ontario, where SAR richness is relatively high and population density is low. However, purchasing land to adequately protect SAR would require a budget much larger than is 
currently available for conservation efforts. Therefore, to effectively protect SAR, we recommend the use of OECMs, such as conservation easements on private land, to supplement protected areas.

We recognize that the conservation of SAR is not as simple as purchasing land and creating protected areas. There are many other factors that go into successful conservation, such as appropriate funding, cooperation with landowners, data availability and accessibility, the management of protected areas after they have been established, and much more. However, given that habitat loss and disturbance is the greatest threat to biodiversity globally and in Canada (Maxwell et al., 2016; McCune et al., 2013; Kerr \& Deguise, 2004), protecting habitat for species at risk should be a cornerstone of any future conservation strategy. 


\section{References}

American White Pelican Recovery Team. (2011). Recovery Strategy for the American White Pelican (Pelecanus erythrorhynchos) in Ontario. Prepared for the Ontario Ministry of Natural Resources. https:/www.ontario.ca/page/american-whitepelican-recovery-strategy

Andrew, M. E., Wulder, M. A., \& Coops, N. C. (2011). Patterns of protection and threats along productivity gradients in Canada. Biological Conservation, 144(12), 28912901. https://doi.org/10.1016/j.biocon.2011.08.006

Armstrong, T. (2014). Management Plan for the Bald Eagle (Haliaeetus leucocephalus) in Ontario. Prepared for the Ontario Ministry of Natural Resources and Forestry. https://www.ontario.ca/page/bald-eagle-management-plan

Arponen, A. (2012). Prioritizing species for conservation planning. Biodiversity and Conservation, 21(4), 875-893. https://doi.org/10.1007/s10531-012-0242-1

Arponen, A., Cabeza, M., Eklund, J., Kujala, H., \& Lehtomäki, J. (2010). Costs of integrating economics and conservation planning. Conservation Biology, 24(5), 1198-1204. https://doi.org/10.1111/j.1523-1739.2010.01539.x

Balmford, A., Gaston, K. J., Blyth, S., James, A., \& Kapos, V. (2003). Global variation in terrestrial conservation costs, conservation benefits, and unmet conservation needs. Proceedings of the National Academy of Sciences of the United States of America, 100(3), 1046-1050. https://doi.org/10.1073/pnas.0236945100

Bennett, J. R., \& Arcese, P. (2013). Human Influence and Classical Biogeographic Predictors of Rare Species Occurrence. Conservation Biology, 27(2), 417-421. https://doi.org/10.1111/cobi.12015

Bergman, J. N., Binley, A. D., Murphy, R. E., \& Proctor, C. A. (2020). How to rescue Ontario' s Endangered Species Act : a biologist's perspective. Facets, 423-431. https://doi.org/10.1139/facets-2019-0050

Beyer, H. L., Dujardin, Y., Watts, M. E., \& Possingham, H. P. (2016). Solving conservation planning problems with integer linear programming. Ecological Modelling, 328, 14-22. https://doi.org/10.1016/j.ecolmodel.2016.02.005

Bode, M., Wilson, K. A., Brooks, T. M., Turner, W. R., Mittermeier, R. A., McBride, M. F., Underwood, E. C., \& Possingham, H. P. (2008). Cost-effective global conservation spending is robust to taxonomic group. Proceedings of the National Academy of Sciences of the United States of America, 105(17), 6498-6501. https://doi.org/10.1073/pnas.0710705105

Bolliger, C. S., Raymond, C. V, Schuster, R., Bennett, J. R., Bolliger, C. S., Raymond, C. V, Schuster, R., Bennett, J. R., Bolliger, C. S., Raymond, C. V, Schuster, R., \& Bennett, J. R. (2020). Spatial coverage of protection for terrestrial species under the Canadian Species at Risk Act Spatial coverage of protection for terrestrial species under the Canadian Species at Risk Act. Écoscience, 27(2), 141-147. https://doi.org/10.1080/11956860.2020.1741497

Burke, P. (2012). Management Plan for the Black Tern (Chlidonias niger) in Ontario. Prepared for the Ontario Ministry of Natural Resources. https://www.ontario.ca/page/black-tern-management-plan\#section-8

Burke, P. (2013). Management Plan for the West Virginia White (Pieris virginiensis) in Ontario. Prepared for the Ontario Ministry of Natural Resources. https://www.ontario.ca/page/west-virginia-white-management-plan\#section-1 
CBD. (2010). Strategic Plan for Biodiversity 2011-2020 and the Aichi Targets. https://www.cbd.int/doc/strategic-plan/2011-2020/Aichi-Targets-EN.pdf

CBD. (2018). Conference of the Parties to the Convention on Biological Diversity Protected areas and other effective area-based coservation measures. https://www.cbd.int/doc/decisions/cop-14/cop-14-dec-08-en.pdf

Cincotta, R., Wisnewski, J., \& Engelman, R. (2000). Human population in the biodiversity hotspots. Nature, 404(April), 25-27.

Coristine, L., Jacob, A., Schuster, R., Otto, S., Baron, N., Bennett, N., Bittick, S., Cody, D., Favaro, B., Ford, A., Nowlan, L., Orihel, D., Palen, W., Polfus, J., Shiddman, D., Venter, O., \& Woodley, S. (2018). Informing Canada' s commitment to biodiversity conservation: A science-based framework to help guide protected areas designation through Target 1 and beyond. FACETS, 531-562. https://doi.org/10.1139/facets2017-0102

COSEWIC. (2013). Little brown myotis, northern myotis and tri-coloured bat: COSEWIC assessment and status report. https://www.canada.ca/en/environmentclimate-change/services/species-risk-public-registry/cosewic-assessments-statusreports/little-brown-myotis-tri-coloured-bat-2013.html\# fig02

COSEWIC. (2015). COSEWIC Assessment Process, Categories and Overview of the COSEWIC Process. https://www.canada.ca/content/dam/eccc/migration/cosewiccosepac/94d0444d-369c-49ed-a586ec00c3fef69b/assessment process and criteria e.pdf

COSEWIC. (2016). Evening grosbeak (Coccothraustes vespertinus): COSEWIC assessment and status report. https://www.canada.ca/en/environment-climatechange/services/species-risk-public-registry/cosewic-assessments-statusreports/evening-grosbeak-2016.html\#_02

COSEWIC. (2017). COSEWIC assessment and status report on the caribou (rangifer tarandus) eastern migratory population, torngat mountains population in Canada. https://www.canada.ca/en/environment-climate-change/services/species-risk-publicregistry/cosewic-assessments-status-reports/caribou-some-populations2017.html\#_02_2_1\%0A

COSSARO. (2007). COSSARO Candidate Species at Risk Evaluation for Slender Bushclover, Lespedeza virginica. http://cossaroagency.ca/wpcontent/uploads/2017/06/Final-COSSARO-Evaluation-Slender-Bush-clover_GFMFINAL-s.pdf

COSSARO. (2016). Ontario Species at Risk Evaluation Report for Algonquin Wolf (Canis sp.), an evolutionarily significant and distinct hybrid with Canis lycaon, $C$. latrans, and C. lupus ancestry. http://cossaroagency.ca/wpcontent/uploads/2017/06/Accessible_COSSARO-evaluation-Algonquin-Wolf.pdf

COSSARO. (2021). Committee on the Status of Species at Risk in Ontario. http://cossaroagency.ca/

Creighton, M. J. A., \& Bennett, J. R. (2019). Taxonomic Biases Persist from Listing to Management for Canadian Species at Risk. Ecoscience, 26(4), 315-321. https://doi.org/10.1080/11956860.2019.1613752

Crins, W. J., Gray, P. A., Uhlig, P. W. C., \& Wester, M. C. (2009). The ecosystems of Ontario, Part 1: Ecozones and ecoregions. In Technical Report SIB TER IMA TR-01.

Deguise, I. E., \& Kerr, J. T. (2006). Protected areas and prospects for endangered species 
conservation in Canada. Conservation Biology, 20(1), 48-55.

https://doi.org/10.1111/j.1523-1739.2005.00274.x

Dinerstein, E., Olson, D., Joshi, A., Vynne, C., Burgess, N. D., Wikramanayake, E., Hahn, N., Palminteri, S., Hedao, P., Noss, R., Hansen, M., Locke, H., Ellis, E. C., Jones, B., Barber, C. V., Hayes, R., Kormos, C., Martin, V., Crist, E., ... Kindt, R. (2017). An Ecoregion-Based Approach to Protecting Half the Terrestrial Realm. BioScience, 67(6). https://doi.org/10.1093/biosci/bix014

Donley, R., Jalava, J. V., \& VanOverbeeke, J. (2013a). Management Plan for the Green Dragon (Arisaema dracontium) in Ontario. Prepared for the Ontario Ministry of Natural Resources. https://www.ontario.ca/page/green-dragon-management-plan

Donley, R., Jalava, J. V., \& VanOverbeeke, J. (2013b). Management Plan for the Shumard Oak (Quercus shumardii) in Ontario. Prepared for the Ontario Ministry of Natural Resources. https://www.ontario.ca/page/shumard-oak-management-plan

Drescher, M., Keith Warriner, G., Farmer, J. R., \& Larson, B. M. H. (2017). Private landowners and environmental conservation: A case study of social-psychological determinants of conservation program participation in Ontario. Ecology and Society, 22(1). https://doi.org/10.5751/ES-09118-220144

Dudley, N., Jonas, H., Nelson, F., Parrish, J., Pyhälä, A., Stolton, S., \& Watson, J. E. M. (2018). The essential role of other effective area-based conservation measures in achieving big bold conservation targets. Global Ecology and Conservation, 15, 1-7. https://doi.org/10.1016/j.gecco.2018.e00424

ECCC. (2016a). 2020 BIODIVERSITY GOALS \& TARGETS FOR CANADA. https://biodivcanada.chm-cbd.net/sites/biodivcanada/files/inline-files/3499 - 2020 Biodiversity Goals \%26 Targets for Canada - Final_ENG.pdf

ECCC. (2016b). Species at Risk Range Map Extents [dataset]. https://open.canada.ca/data/en/dataset/d00f8e8c-40c4-435a-b790-980339ce3121

ECCC. (2020). CANADA'S CONSERVED AREAS: CANADIAN ENVIRONMENTAL SUSTAINABILITY INDICATORS.

Endangered Species Act. (2007). S.O. 2007, c.6. https://www.ontario.ca/laws/statute/07e06

ESRI Inc. (2019). ArcGIS (10.7). ESRI Inc. https://desktop.arcgis.com/en/

Farmer, J. R., Ma, Z., Drescher, M., Knackmuhs, E. G., \& Dickinson, S. L. (2017). Private Landowners, Voluntary Conservation Programs, and Implementation of Conservation Friendly Land Management Practices. Conservation Letters, 10(1), 58-66. https://doi.org/10.1111/conl.12241

Guribi Optimization, L. (2021). Gurobi (9.0.3). http://www.gurobi.com

Hanson, J., Schuster, R., Morrell, N., M, S.-M., Watts, M., Arcese, P., Bennett, J., \& Possingham, H. (2021). prioritizr: Systematic Conservation Prioritization in $R(\mathrm{R}$ package version 5.0.3).

Harris, A. G. (2018). Recovery Strategy for the Hoptree Borer (Prays atomocella) in Ontario. Prepared for the Ontario Ministry of Environment, Conservation and Parks. https://www.ontario.ca/page/hoptree-borer-recovery-strategy\#section-1

Hossie, T. (2018). Recovery Strategy for Small-mouthed Salamander (Ambystoma texanum) and Unisexual Ambystoma Small-mouthed Salamander dependent population (Ambystoma laterale - texanum) in Ontario. Prepared for the Ontario Ministry of Natural Resources and Forestry. https://www.ontario.ca/page/small- 
mouthed-salamander-and-small-mouthed-dependent-unisexual-ambystomarecovery-strategy

Humphrey, C. (2017). Recovery Strategy for the Eastern Small-footed Myotis (Myotis leibii) in Ontario. Prepared for the Ontario Ministry of Natural Resources and Forestry. https://files.ontario.ca/mnrf_sar_rs_esfm_final_accessible.pdf

Jetz, W., Sekercioglu, C. H., \& Watson, J. E. M. (2008). Ecological Correlates and Conservation Implications of Overestimating Species Geographic Ranges. Conservation Biology, 22(1), 110-119. https://doi.org/10.1111/j.15231739.2007.00847.x

Jonas, H. D., Lee, E., Jonas, H. C., Matallana-tobon, C., Wright, K. S., Nelson, F., \& Enns, E. (2017). WILL ' OTHER EFFECTIVE AREA - BASED CONSERVATION MEASURES ' INCREASE RECOGNITION AND SUPPORT FOR ICCA ? PARKS, 23(November).

Jones, J. (2018). Recovery Strategy for the Lake Huron Grasshopper (Trimerotropis huroniana) in Ontario. Prepared for the Ontario Ministry of Environment, Conservation and Parks. https://www.ontario.ca/page/lake-huron-grasshopperrecovery-strategy\#section-1

Kamal, S., Grodzińska-Jurczak, M., \& Brown, G. (2015). Conservation on private land: a review of global strategies with a proposed classification system. Journal of Environmental Planning and Management, 58(4), 576-597. https://doi.org/10.1080/09640568.2013.875463

Kerr, J. T., \& Cihlar, J. (2004). Patterns and causes of species endangerment in Canada. Ecological Applications, 14(3), 743-753. https://doi.org/10.1890/02-5117

Kerr, J. T., \& Deguise, I. (2004). Habitat loss and the limits to endangered species recovery. Ecology Letters, 7(12), 1163-1169. https://doi.org/10.1111/j.14610248.2004.00676.x

Knight, T. (2019). Recovery Strategy for the Golden-eye Lichen (Teloschistes chrysophthalmus) - Great Lakes population in Ontario. Prepared for the Ministry of the Environment, Conservation and Parks. https://www.ontario.ca/page/golden-eyelichen-great-lakes-population-recovery-strategy

Kraus, D., \& Hebb, A. (2020). Southern Canada's crisis ecoregions: identifying the most significant and threatened places for biodiversity conservation. Biodiversity and Conservation, 0123456789, 3573-3590.

Kukkala, A. S., \& Moilanen, A. (2013). Core concepts of spatial prioritisation in systematic conservation planning. Biological Reviews, 88(2), 443-464. https://doi.org/10.1111/brv.12008

Lemieux, C. J., Beechey, T. J., \& Gray, P. A. (2011). Prospects for Canada's protected areas in an era of rapid climate change. Land Use Policy, 28(4), 928-941. https://doi.org/10.1016/j.landusepol.2011.03.008

Lemieux, C. J., Gray, P. A., Devillers, R., Wright, P. A., Dearden, P., Halpenny, E. A., Groulx, M., Beechey, T. J., \& Beazley, K. (2019). How the race to achieve Aichi Target 11 could jeopardize the effective conservation of biodiversity in Canada and beyond. Marine Policy, 99(November 2018), 312-323. https://doi.org/10.1016/j.marpol.2018.10.029

Lemieux, C. J., \& Scott, D. J. (2011). Changing climate, challenging choices: Identifying and evaluating climate change adaptation options for protected areas management in 
Ontario, Canada. Environmental Management, 48(4), 675-690.

https://doi.org/10.1007/s00267-011-9700-x

Linton, J., McCarter, J., \& Fotherby, H. (2018). Recovery Strategy for the Jefferson

Salamander (Ambystoma jeffersonianum) and Unisexual Ambystoma (Jefferson

Salamander dependent population) (Ambystoma laterale - (2) jeffersonianum) in

Ontario. Prepared for the Ontario Ministry of Natural Resources.

https://www.ontario.ca/page/jefferson-salamander-and-jefferson-dependentunisexual-ambystoma-recovery-strategy

Linton, J., \& McCorquodale, D. (2018). Recovery Strategy for the Nine-spotted Lady Beetle (Coccinella novemnotata) in Ontario. Prepared for the Ontario Ministry of Natural Resources and Forestry. https://www.ontario.ca/page/nine-spotted-ladybeetle-recovery-strategy\#section-1

Linton, J., \& McCorquodale, D. (2019). Recovery Strategy for the Transverse Lady Beetle (Coccinella transversoguttata) in Ontario. Prepared for the Ontario Ministry of Environment, Conservation and Parks. https://www.ontario.ca/page/transverselady-beetle-recovery-strategy

Locke, H. (2014). Nature Needs Half : A Necessary and Hopeful New Agenda for Protected Areas in North America and around the World. George Wright Society Nature, 31(3), 359-371.

Lysyk, B., \& DeMarco, J. (2020). 2020 Annual Report of Environmental Value-forMoney Audits and the Operation of the Environmental Bill of Rights Reflections (Vol. 51, Issue 1).

Margules, C. R., \& Pressey, R. L. (2000). Systematic conservation planning. Nature, 405(6783), 243-253. https://doi.org/10.1038/35012251

Maxwell, S. L., Fuller, R. A., Brooks, T. M., \& Watson, J. E. M. (2016). Biodiversity: The ravages of guns, nets and bulldozers. Nature, 536(7615), 143-145. https://doi.org/10.1038/536143a

McCarthy, D. P., Donald, P. F., Scharlemann, J. P. W., Buchanan, G. M., Balmford, A., Green, J. M. H., Bennun, L. A., Burgess, N. D., Fishpool, L. D. C., Garnett, S. T., Leonard, D. L., Maloney, R. F., Morling, P., Schaefer, H. M., Symes, A., Wiedenfeld, D. A., \& Butchart, S. H. M. (2012). Financial costs of meeting global biodiversity conservation targets: Current spending and unmet needs. Science, 338(6109), 946-949. https://doi.org/10.1126/science.1229803

Mccune, J. (2019). A new record of Stylophorum diphyllum (Michx.) Nutt. in Canada: A case study of the value and limitations of building species distribution models for very rare plants. The Journal of the Torrey Botanical Society, 14(2), 119-127.

Mccune, J. L. (2016). Species distribution models predict rare species occurrences despite significant effects of landscape context. Journal of Applied Ecology, 18711879. https://doi.org/10.1111/1365-2664.12702

McCune, J. L., Harrower, W. L., Avery-Gomm, S., Brogan, J. M., Csergo, A. M., Davidson, L. N. K., Garani, A., Halpin, L. R., Lipsen, L. P. J., Lee, C., Nelson, J. C., Prugh, L. R., Stinson, C. M., Whitney, C. K., \& Whitton, J. (2013). Threats to Canadian species at risk: An analysis of finalized recovery strategies. Biological Conservation, 166, 254-265. https://doi.org/10.1016/j.biocon.2013.07.006

Mooers, A. O., Doak, D. F., Findlay, C. S., Green, D. M., Grouios, C., Manne, L. L., Rashvand, A., Rudd, M. A., \& Whitton, J. (2010). Science, Policy, and Species at 
Risk in Canada. BioScience, 60(10), 843-849.

https://doi.org/10.1525/bio.2010.60.10.11

Murdoch, W., Polasky, S., Wilson, K. A., Possingham, H. P., Kareiva, P., \& Shaw, R. (2007). Maximizing return on investment in conservation. Biological Conservation, 139(3-4), 375-388. https://doi.org/10.1016/j.biocon.2007.07.011

Myers, N., Mittermeierf, R. A., Mittermeierf, C. G., Fonsecat, G. A. B., \& Kent, J. (2000). Biodiversity hotspots for conservation priorities. Nature, 403(February).

Naidoo, R., \& Adamowicz, W. L. (2006). Modeling opportunity costs of conservation in transitional landscapes. Conservation Biology, 20(2), 490-500. https://doi.org/10.1111/j.1523-1739.2006.00304.x

Naidoo, R., Balmford, A., Ferraro, P. J., Polasky, S., Ricketts, T. H., \& Rouget, M. (2006). Integrating economic costs into conservation planning. Trends in Ecology and Evolution, 21(12), 681-687. https://doi.org/10.1016/j.tree.2006.10.003

Natural Resource Canada. (2017). Aboriginal Lands of Canada Legislative Boundaries [dataset]. https://open.canada.ca/data/en/dataset/522b07b9-78e2-4819-b736ad9208eb1067

Nature Conservancy of Canada. (2018). NCC Properties [dataset].

Nixon, S., Page, D., Pinkus, S., Podolsky, L., \& Russell, S. (2012). GRADING CANADA ' S SPECIES AT RISK LAWS.

Olive, A. (2014). Land, stewardship, and legitimacy: endangered species policy in Canada and the United States. University of Toronto Press.

Olive, A., \& Penton, G. (2018). Species at risk in Ontario: An examination of environmental non-governmental organizations. Canadian Geographer, 62(4), 562574. https://doi.org/10.1111/cag.12483

OMECP. (2019a). American Hart's Tongue Fern. https://www.ontario.ca/page/americanharts-tongue-fern

OMECP. (2019b). State of Ontario's Protected Areas Report. https:/www.ontario.ca/page/state-ontarios-protected-areas-report

OMECP. (2019c). Yellow-banded Bumble Bee. https://www.ontario.ca/page/yellowbanded-bumble-bee

OMECP. (2020). S.O. 2006, c. 12, 2006, Provincial Parks and Conservation Reserves Act. https://www.ontario.ca/laws/statute/06p12

OMECP. (2021). Ontario's parks and protected areas. https://www.ontario.ca/page/ontarios-parks-and-protected-areas

OMNRF. (2012). Crown Land Use Policy Atlas Overlay. https://geohub.lio.gov.on.ca/datasets/clupa-overlay

OMNRF. (2017). Buildings to Scale. Provincial Mapping Unity. https://geohub.lio.gov.on.ca/datasets/mnrf::building-to-scale

OMNRF. (2018a). Federal Protected Areas [dataset]. https://geohub.lio.gov.on.ca/datasets/federal-protected-areas

OMNRF. (2018b). Ontario Land Cover Compilation v.2.0. https:/geohub.lio.gov.on.ca/datasets/7aa998fdf100434da27a41f1c637382c

OMNRF. (2019a). Conservation Land Tax Incentive Program. https://www.ontario.ca/page/conservation-land-tax-incentive-program

OMNRF. (2019b). Conservation Reserve Regulated [dataset]. https://geohub.lio.gov.on.ca/datasets/conservation-reserve-regulated?geometry=- 
$140.240 \% 2 \mathrm{C} 38.917 \% 2 \mathrm{C}-29.234 \% 2 \mathrm{C} 58.786$

OMNRF. (2019c). Federal Lands Other [dataset]. https://geohub.lio.gov.on.ca/datasets/federal-land-other

OMNRF. (2019d). NGO Nature Reserves [dataset]. https://geohub.lio.gov.on.ca/datasets/ngo-nature-reserve

OMNRF. (2019e). Provincial Parks Regulated [dataset]. https://geohub.lio.gov.on.ca/datasets/provincial-park-regulated?geometry=$140.240 \% 2 \mathrm{C} 38.917 \% 2 \mathrm{C}-29.234 \% 2 \mathrm{C} 58.786$

OMNRF. (2020a). Crown land management. https://www.ontario.ca/page/crown-landmanagement

OMNRF. (2020b). R.S.O. 1990, c. P.43, Public Lands Act. https://www.ontario.ca/laws/statute/90p43

OMNRF. (2021). Ontario Crown Land Use Policy Atlas. https://www.ontario.ca/page/crown-land-use-policy-atlas

Ontario Parks. (2002). Ojibway Prairie Provincial Park Management Plan. https://www.ontario.ca/page/ojibway-prairie-provincial-park-management-plan

Ottewell, K. M., Bickerton, D. C., Byrne, M., \& Lowe, A. J. (2016). Bridging the gap: a genetic assessment framework for population-level threatened plant conservation prioritization and decision-making. 174-188. https://doi.org/10.1111/ddi.12387

Pimm, S. L., Jenkins, C. N., Abell, R., Brooks, T. M., Gittkeman, J. L., Joppa, L. N., Raven, P. H., Roberts, C. M., \& Sexton, J. O. (2014). The biodiversity of species and their rates of extinction, distribution, and protection. Science, 344(6187). $\mathrm{https}$ ://doi.org/10.1126/science. 1246752

Rissman, A. R., Lozier, L., Comendant, T., Kareiva, P., Kiesecker, J. M., Shaw, M. R., \& Merenlender, A. M. (2007). Conservation easements: Biodiversity protection and private use. Conservation Biology, 21(3), 709-718. https://doi.org/10.1111/j.15231739.2007.00660.x

Robillard, C. M., \& Kerr, J. T. (2017). Assessing the shelf life of cost-efficient conservation plans for species at risk across gradients of agricultural land use. Conservation Biology, 31(4), 837-847. https://doi.org/10.1111/cobi.12886

Rosner-katz, H., Mccune, J. L., \& Bennett, J. R. (2020). Using stacked SDMs with accuracy and rarity weighting to optimize surveys for rare plant species. Biodiversity and Conservation, 29(11), 3209-3225. https://doi.org/10.1007/s10531-020-02018-1

SARA. (2021). C-29. An Act Respecting the Protection of Wildlife Species at Risk in Canada. https://laws-lois.justice.gc.ca/eng/acts/S-15.3/index.html

SARO. (2018). O.reg. 230/08: Species at Risk in Ontario List under Endangered Species Act, 2007, S.O. 2007, C.6. https://www.ontario.ca/laws/regulation/080230

Schuster, R., Germain, R. R., Bennett, J. R., Reo, N. J., \& Arcese, P. (2019). Vertebrate biodiversity on indigenous-managed lands in Australia, Brazil, and Canada equals that in protected areas. Environmental Science and Policy, 101(June), 1-6. https://doi.org/10.1016/j.envsci.2019.07.002

Schuster, R., Law, E. A., Rodewald, A. D., Martin, T. G., Wilson, K. A., Watts, M., Possingham, H. P., \& Arcese, P. (2017). Tax Shifting and Incentives for Biodiversity Conservation on Private Lands. In Conservation Letters (Vol. 11, Issue 2). https://doi.org/10.1111/conl.12377

Schuster, R., Wilson, S., Rodewald, A. D., Arcese, P., Fink, D., Auer, T., \& Bennett, J. R. 
(2019). Optimizing the conservation of migratory species over their full annual cycle. Nature Communications, 10(1), 1-8. https://doi.org/10.1038/s41467-01909723-8

Statistics Canada. (2016). Population Centre Boundary File. Government of Canada. https://www150.statcan.gc.ca/n1/en/catalogue/92-166-X

Stewart, R. R., \& Possingham, H. P. (2005). Efficiency, costs and trade-offs in marine reserve system design. Environmental Modeling and Assessment, 10(3), 203-213. https://doi.org/10.1007/s10666-005-9001-y

Svancara, L. K., Brannon, R. E. E., Scott, J. M., Groves, C. R., Noss, R. F., \& Pressey, R. L. (2005). Policy-driven versus Evidence- based Conservation: A Review of Political Targets and Biological Needs. BioScience, 55(11), 989-995.

TERANET. (2020). Geowarehouse. https://www2.geowarehouse.ca/

Trudeau, J. (2019). Minister of Environment and Climate Change Mandate Letter. https://pm.gc.ca/en/mandate-letters/2019/12/13/minister-environment-and-climatechange-mandate-letter

Venter, O., Brodeur, N. N., Nemiroff, L., Belland, B., Dolinsek, I. J., \& Grant, J. W. A. (2006). Threats to Endangered Species in Canada. BioScience, 56(11), 903-910.

Willson, R. J., \& Cunnington, G. M. (2015). Recovery Strategy for the Lake Erie Watersnake (Nerodia sipedon insularum) in Ontario. Prepared for the Ontario Ministry of Natural Resources and Foresty. https://www.ontario.ca/page/lake-eriewatersnake-recovery-strategy

Wilson, K. A., Cabeza, M., \& Klein, C. J. (2009). Fundamental concepts of spatial conservation prioritization. Spatial Conservation Prioritization: Quantitative Methods and Computational Tools, 16-27.

Wilson, K. A., Carwardine, J., \& Possingham, H. P. (2009). Setting conservation priorities. Annals of the New York Academy of Sciences, 1162, 237-264. https://doi.org/10.1111/j.1749-6632.2009.04149.x

Wyshynski, S., Eads, A. R., \& Nicolai, A. (2019). Recovery Strategy for the Eastern Banded Tigersnail (Anguispira kochi kochi) in Ontario. Prepared for the Ministry of the Environment, Conservation and Parks. https://www.ontario.ca/page/easternbanded-tigersnail-recovery-strategy

Wyshynski, S., \& Nicolai, A. (2018). Recovery Strategy for the Proud Globelet (Patera pennsylvanica) in Ontario. Prepared for the Ontario Ministry of Environment, Conservation and Parks. https://www.ontario.ca/page/proud-globelet-recoverystrategy

Wyshynski, S., \& Pulfer, T. L. (2015). Recovery Strategy for the Golden Eagle (Aquila chrysaetos) in Ontario. Prepared for the Ontario Ministry of Natural Resources and Forestry. https://www.ontario.ca/page/golden-eagle-recovery-strategy 


\section{Appendix A: Supplemental Tables}

Table A1. Species and their threat level listed on the Species at Risk in Ontario List (SARO, 2018) with habitat requirements and range information source

\begin{tabular}{|c|c|c|c|}
\hline Species & Threat level & $\begin{array}{l}\text { Habitat } \\
\text { Types* }\end{array}$ & Source \\
\hline Acadian Flycatcher & Endangered & $\begin{array}{l}\mathrm{dtr} \\
\mathrm{mtr} \\
\mathrm{swp}\end{array}$ & (ECCC, 2016b) \\
\hline Algonquin Wolf & Threatened & $\begin{array}{l}\mathrm{mtr} \\
\mathrm{ctr}\end{array}$ & (COSSARO, 2016) \\
\hline $\begin{array}{l}\text { Allegheny Mountain Dusky Salamander } \\
\text { (Carolinian population) }\end{array}$ & Endangered & $\begin{array}{l}\mathrm{mtr} \\
\mathrm{dtr} \\
\mathrm{str} \\
\mathrm{ctr}\end{array}$ & (ECCC, 2016b) \\
\hline $\begin{array}{l}\text { Allegheny Mountain Dusky Salamander } \\
\text { (Great Lakes / St. Lawrence population) }\end{array}$ & Endangered & $\begin{array}{l}\mathrm{mtr} \\
\mathrm{dtr} \\
\text { str } \\
\mathrm{ctr}\end{array}$ & (ECCC, 2016b) \\
\hline American Badger jacksoni subspecies & Endangered & $\begin{array}{l}\operatorname{tgp} \\
\text { tgs } \\
\text { snd } \\
\text { agr }\end{array}$ & (ECCC, 2016b) \\
\hline $\begin{array}{l}\text { American Badger jeffersonii subspecies } \\
\text { (Eastern population) }\end{array}$ & Endangered & $\begin{array}{l}\operatorname{tgp} \\
\text { tgs } \\
\text { snd } \\
\text { agr }\end{array}$ & (ECCC, 2016b) \\
\hline American Chestnut & Endangered & tru & (ECCC, 2016b) \\
\hline American Columbo & Endangered & $\begin{array}{l}\text { tru } \\
\text { dtr } \\
\text { swp } \\
\text { tgw } \\
\text { str }\end{array}$ & (ECCC, 2016b) \\
\hline American Ginseng & Endangered & drt & (ECCC, 2016b) \\
\hline American Water-willow & Threatened & $\begin{array}{l}\text { shr } \\
\text { mud } \\
\text { msh } \\
\text { swp } \\
\text { fen } \\
\text { bog }\end{array}$ & (ECCC, 2016b) \\
\hline American White Pelican & Threatened & $\begin{array}{c}\text { bdr } \\
\text { snd } \\
\text { alv } \\
\text { mud } \\
\text { str } \\
\text { shr }\end{array}$ & $\begin{array}{l}\text { (American White } \\
\text { Pelican Recovery } \\
\text { Team, 2011) }\end{array}$ \\
\hline Aweme Borer & Endangered & $\begin{array}{l}\text { tgp } \\
\text { tgs } \\
\text { snd }\end{array}$ & (ECCC, 2016b) \\
\hline Bald Eagle & Special Concern & $\begin{array}{c}\text { str } \\
\mathrm{dtr} \\
\mathrm{ctr} \\
\mathrm{mtr} \\
\mathrm{tru} \\
\mathrm{tgw}\end{array}$ & (Armstrong, 2014) \\
\hline Bank Swallow & Threatened & $\begin{array}{l}\text { snd } \\
\text { shr } \\
\text { sgm } \\
\text { com } \\
\text { agr }\end{array}$ & (ECCC, 2016b) \\
\hline Barn Owl (Eastern population) & Endangered & com & (ECCC, 2016b) \\
\hline
\end{tabular}




\begin{tabular}{|c|c|c|c|}
\hline & & agr & \\
\hline Barn Swallow & Threatened & $\begin{array}{c}\text { com } \\
\text { agr }\end{array}$ & (ECCC, 2016b) \\
\hline Bashful Bulrush & Endangered & $\begin{array}{l}\text { dtr } \\
\text { str } \\
\text { tgs }\end{array}$ & (ECCC, 2016b) \\
\hline $\begin{array}{l}\text { Bent Spike-rush (Great Lakes Plains } \\
\text { population) }\end{array}$ & Endangered & $\begin{array}{l}\text { shr } \\
\text { mud } \\
\text { msh }\end{array}$ & (ECCC, 2016b) \\
\hline Bird's-foot Violet & Endangered & tgs & (ECCC, 2016b) \\
\hline Black Tern & Special Concern & $\begin{array}{l}\text { msh } \\
\text { swp }\end{array}$ & (Burke, 2012) \\
\hline $\begin{array}{l}\text { Blanding's Turtle (Great Lakes / St. } \\
\text { Lawrence population) }\end{array}$ & Threatened & $\begin{array}{l}\text { msh } \\
\text { swp } \\
\text { fen } \\
\text { bog }\end{array}$ & (ECCC, 2016b) \\
\hline Blue Ash & Threatened & $\begin{array}{l}\text { dtr } \\
\text { shr } \\
\text { mud }\end{array}$ & (ECCC, 2016b) \\
\hline Blue Racer & Endangered & $\begin{array}{l}\text { het } \\
\text { agr } \\
\text { alv } \\
\text { tgp } \\
\text { tgs } \\
\text { tgw } \\
\text { str }\end{array}$ & (ECCC, 2016b) \\
\hline Bluehearts & Endangered & $\begin{array}{l}\text { snd } \\
\text { shr } \\
\text { tgp } \\
\text { het }\end{array}$ & (ECCC, 2016b) \\
\hline Blunt-lobed Woodsia & Endangered & $\begin{array}{l}\text { clf } \\
b d r \\
d t r\end{array}$ & (ECCC, 2016b) \\
\hline Bobolink & Threatened & $\begin{array}{l}\text { het } \\
\text { tgp } \\
\text { tgs } \\
\text { agr }\end{array}$ & (ECCC, 2016b) \\
\hline Bogbean Buckmoth & Endangered & fen & (ECCC, 2016b) \\
\hline Branched Bartonia & Threatened & $\begin{array}{l}\text { bog } \\
\text { fen }\end{array}$ & (ECCC, 2016b) \\
\hline Broad-banded Forestsnail & Endangered & $\begin{array}{l}\text { dtr } \\
\mathrm{mtr} \\
\mathrm{ctr} \\
\mathrm{alv} \\
\mathrm{tru} \\
\mathrm{str}\end{array}$ & (ECCC, 2016b) \\
\hline Butler's Gartersnake & Endangered & $\begin{array}{l}\text { het } \\
\text { bog } \\
\text { fen } \\
\text { msh } \\
\text { agr }\end{array}$ & (ECCC, 2016b) \\
\hline Butternut & Endangered & $\mathrm{dtr}$ & (ECCC, 2016b) \\
\hline Canada Warbler & Special Concern & $\begin{array}{l}\mathrm{dtr} \\
\mathrm{ctr} \\
\mathrm{mtr} \\
\mathrm{tgw}\end{array}$ & (ECCC, 2016b) \\
\hline Caribou (Eastern Migratory) & Special Concern & $\begin{array}{l}\text { msh } \\
\text { fen } \\
\text { bog } \\
\text { het } \\
\text { str } \\
\text { dtr } \\
\mathrm{mtr}\end{array}$ & (COSEWIC, 2017) \\
\hline
\end{tabular}




\begin{tabular}{|c|c|c|c|}
\hline & & $\begin{array}{l}\text { ctr } \\
\text { pla } \\
\text { tru }\end{array}$ & \\
\hline Cerulean Warbler & Threatened & $\begin{array}{l}\text { dtr } \\
\text { tru } \\
\text { str }\end{array}$ & (ECCC, 2016b) \\
\hline Cherry Birch & Endangered & dtr & (ECCC, 2016b) \\
\hline Chimney Swift & Threatened & com & (ECCC, 2016b) \\
\hline Climbing Prairie Rose & Special Concern & $\begin{array}{l}\text { tgp } \\
\text { agr } \\
\text { het }\end{array}$ & (ECCC, 2016b) \\
\hline Colicroot & Endangered & $\begin{array}{l}\text { het } \\
\text { tgp } \\
\text { tgs } \\
\text { agr }\end{array}$ & (ECCC, 2016b) \\
\hline Common Hoptree & Special Concern & shr & (ECCC, 2016b) \\
\hline Common Nighthawk & Special Concern & $\begin{array}{c}\text { str } \\
\text { bdr } \\
\text { bog } \\
\text { shr } \\
\text { alv } \\
\text { mud }\end{array}$ & (ECCC, 2016b) \\
\hline Crooked-stem Aster & Special Concern & str & (ECCC, 2016b) \\
\hline Cucumber Tree & Endangered & $\begin{array}{l}\mathrm{dtr} \\
\mathrm{mtr} \\
\mathrm{swp}\end{array}$ & (ECCC, 2016b) \\
\hline Deerberry & Threatened & $\begin{array}{c}\mathrm{dtr} \\
\mathrm{ctr} \\
\mathrm{mtr} \\
\mathrm{str}\end{array}$ & (ECCC, 2016b) \\
\hline Dense Blazing Star & Threatened & $\begin{array}{l}\text { tgp } \\
\text { tgs } \\
\text { snd } \\
\text { agr }\end{array}$ & (ECCC, 2016b) \\
\hline Drooping Trillium & Endangered & dtr & (ECCC, 2016b) \\
\hline Dwarf Hackberry & Threatened & $\begin{array}{l}\text { shr } \\
\text { alv } \\
\text { tgs } \\
\text { snd }\end{array}$ & (ECCC, 2016b) \\
\hline Dwarf Lake Iris & Special Concern & $\begin{array}{c}\text { ctr } \\
\text { swp } \\
\text { alv } \\
\text { str }\end{array}$ & (ECCC, 2016b) \\
\hline Eastern Banded Tigersnail & Endangered & $\begin{array}{l}\mathrm{dtr} \\
\mathrm{ctr} \\
\mathrm{mtr}\end{array}$ & $\begin{array}{l}\text { (Wyshynski et al., } \\
\text { 2019) }\end{array}$ \\
\hline Eastern Flowering Dogwood & Endangered & $\begin{array}{l}\mathrm{dtr} \\
\mathrm{mtr}\end{array}$ & (ECCC, 2016b) \\
\hline Eastern Foxsnake (Carolinian population) & Endangered & $\begin{array}{l}\text { agr } \\
\text { msh } \\
\text { hed } \\
\text { shr } \\
\text { tgp }\end{array}$ & (ECCC, 2016b) \\
\hline $\begin{array}{l}\text { Eastern Foxsnake (Great Lakes / St. } \\
\text { Lawrence population) }\end{array}$ & Threatened & $\begin{array}{l}\text { agr } \\
\text { msh } \\
\text { hed } \\
\text { shr } \\
\text { tgp }\end{array}$ & (ECCC, 2016b) \\
\hline Eastern Hog-nosed Snake & Threatened & $\begin{array}{l}\mathrm{shr} \\
\mathrm{tru} \\
\mathrm{dtr} \\
\mathrm{mtr}\end{array}$ & (ECCC, 2016b) \\
\hline
\end{tabular}




\begin{tabular}{|c|c|c|c|}
\hline & & $\begin{array}{l}\text { ctr } \\
\text { str } \\
\text { snd } \\
\text { agr } \\
\text { tgp } \\
\text { tgw }\end{array}$ & \\
\hline Eastern Meadowlark & Threatened & $\begin{array}{l}\text { agr } \\
\text { tgp } \\
\text { tgs }\end{array}$ & (ECCC, 2016b) \\
\hline Eastern Mole & Special Concern & $\begin{array}{l}\text { dtr } \\
\mathrm{ctr} \\
\text { tru } \\
\mathrm{mtr} \\
\mathrm{str} \\
\mathrm{tgw} \\
\mathrm{tgp} \\
\mathrm{tgs} \\
\mathrm{agr} \\
\mathrm{com}\end{array}$ & (ECCC, 2016b) \\
\hline Eastern Musk Turtle & Special Concern & msh & (ECCC, 2016b) \\
\hline Eastern Prairie Fringed-orchid & Endangered & $\begin{array}{l}\text { bog } \\
\text { fen } \\
\text { swp } \\
\text { tgp }\end{array}$ & (ECCC, 2016b) \\
\hline Eastern Prickly Pear Cactus & Endangered & $\begin{array}{l}\text { shr } \\
\text { snd } \\
\text { alv } \\
\text { tgs } \\
\text { tgp } \\
\text { str }\end{array}$ & (ECCC, 2016b) \\
\hline $\begin{array}{l}\text { Eastern Ribbonsnake (Great Lakes } \\
\text { population) }\end{array}$ & Special Concern & $\begin{array}{l}\text { msh } \\
\text { swp } \\
\text { bog } \\
\text { fen }\end{array}$ & (ECCC, 2016b) \\
\hline Eastern Small-footed Myotis & Endangered & $\begin{array}{c}\text { com } \\
\text { clf } \\
\mathrm{sgm} \\
\mathrm{str} \\
\mathrm{mtr} \\
\mathrm{dtr} \\
\mathrm{ctr}\end{array}$ & (Humphrey, 2017) \\
\hline Eastern Whip-poor-will & Threatened & $\begin{array}{l}\text { tgs } \\
\text { tgp } \\
\text { tgw } \\
\text { str } \\
\text { agr } \\
\mathrm{ctr} \\
\mathrm{dtr} \\
\mathrm{mtr} \\
\text { tru }\end{array}$ & (ECCC, 2016b) \\
\hline Eastern Wood-pewee & Special Concern & $\begin{array}{c}\mathrm{dtr} \\
\mathrm{mtr} \\
\mathrm{str} \\
\mathrm{tgw}\end{array}$ & (ECCC, 2016b) \\
\hline Evening Grosbeak & Special Concern & $\begin{array}{l}\mathrm{mtr} \\
\mathrm{ctr} \\
\mathrm{com}\end{array}$ & (COSEWIC, 2016) \\
\hline False Hop Sedge & Endangered & $\begin{array}{l}\text { swp } \\
\text { msh } \\
\text { str }\end{array}$ & (ECCC, 2016b) \\
\hline False Rue-anemone & Threatened & dtr & (ECCC, 2016b) \\
\hline Five-lined Skink (Carolinian population) & Endangered & $\begin{array}{l}\text { snd } \\
\text { str } \\
\text { tgw }\end{array}$ & (ECCC, 2016b) \\
\hline
\end{tabular}




\begin{tabular}{|c|c|c|c|}
\hline & & $\begin{array}{l}\text { msh } \\
\text { swp } \\
\text { bog } \\
\text { fen }\end{array}$ & \\
\hline $\begin{array}{l}\text { Five-lined Skink (Great Lakes / St. } \\
\text { Lawrence population) }\end{array}$ & Special Concern & $\begin{array}{l}\text { snd } \\
\text { str } \\
\text { bdr } \\
\text { alv }\end{array}$ & (ECCC, 2016b) \\
\hline Forked Three-awned Grass & Endangered & $\begin{array}{l}\text { tgp } \\
\text { agr } \\
\text { tgs } \\
\text { snd }\end{array}$ & (ECCC, 2016b) \\
\hline Four-leaved Milkweed & Endangered & $\begin{array}{l}\text { dtr } \\
\text { str }\end{array}$ & (ECCC, 2016b) \\
\hline Fowler's Toad & Endangered & $\begin{array}{l}\text { shr } \\
\text { mud } \\
\text { snd } \\
\text { msh } \\
\text { swp } \\
\text { fen }\end{array}$ & (ECCC, 2016b) \\
\hline Gattinger's Agalinis & Endangered & $\begin{array}{l}\text { alv } \\
\text { tgp } \\
\text { tgs }\end{array}$ & (ECCC, 2016b) \\
\hline Golden Eagle & Endangered & $\begin{array}{c}\text { clf } \\
\text { agr } \\
\text { str } \\
\text { tru } \\
\mathrm{mtr} \\
\mathrm{dtr} \\
\mathrm{trgw} \\
\mathrm{ctr}\end{array}$ & $\begin{array}{l}\text { (Wyshynski \& } \\
\text { Pulfer, 2015) }\end{array}$ \\
\hline Golden-eyed Lichen & Endangered & $\begin{array}{l}\mathrm{mtr} \\
\mathrm{str} \\
\mathrm{ctr} \\
\mathrm{dtr} \\
\mathrm{shr} \\
\mathrm{tru} \\
\mathrm{tgw}\end{array}$ & (Knight, 2019) \\
\hline Goldenseal & Threatened & $\begin{array}{l}\text { str } \\
\text { dtr }\end{array}$ & (ECCC, 2016b) \\
\hline Golden-winged Warbler & Special Concern & $\begin{array}{l}\text { str } \\
\text { pla } \\
\text { hed } \\
\text { agr }\end{array}$ & (ECCC, 2016b) \\
\hline $\begin{array}{l}\text { Grasshopper Sparrow, pratensis } \\
\text { subspecies }\end{array}$ & Special Concern & $\begin{array}{l}\text { tgp } \\
\text { tgs } \\
\text { agr } \\
\text { alv }\end{array}$ & (ECCC, 2016b) \\
\hline Gray Fox & Threatened & $\begin{array}{c}\mathrm{msh} \\
\mathrm{dtr}\end{array}$ & (ECCC, 2016b) \\
\hline Gray Ratsnake (Carolinian population) & Endangered & $\begin{array}{l}\text { agr } \\
\text { dtr } \\
\text { tgp } \\
\text { tgw } \\
\text { tgs }\end{array}$ & (ECCC, 2016b) \\
\hline $\begin{array}{l}\text { Gray Ratsnake (Great Lakes / St. } \\
\text { Lawrence population) }\end{array}$ & Threatened & $\begin{array}{l}\text { dtr } \\
\text { msh } \\
\text { swp } \\
\text { fen } \\
\text { bog } \\
\text { agr } \\
\text { bdr }\end{array}$ & (ECCC, 2016b) \\
\hline Green Dragon & Special Concern & dtr & $\begin{array}{l}\text { (Donley et al., } \\
\text { 2013a) }\end{array}$ \\
\hline
\end{tabular}




\begin{tabular}{|c|c|c|c|}
\hline Gypsy Cuckoo Bumble Bee & Endangered & $\begin{array}{c}\text { mtr } \\
\mathrm{dtr} \\
\mathrm{ctr} \\
\mathrm{agr} \\
\mathrm{tgp} \\
\text { tgs } \\
\mathrm{com}\end{array}$ & (ECCC, 2016b) \\
\hline Hart's-tongue Fern & Special Concern & dtr & (OMECP, 2019a) \\
\hline Heart-leaved Plantain & Endangered & $\begin{array}{l}\text { alv } \\
\text { pla } \\
\text { dtr }\end{array}$ & (ECCC, 2016b) \\
\hline Henslow's Sparrow & Endangered & $\begin{array}{l}\text { tgp } \\
\text { tgs } \\
\text { agr }\end{array}$ & (ECCC, 2016b) \\
\hline Hill's Thistle & Threatened & $\begin{array}{l}\text { alv } \\
\text { tgp } \\
\text { tgs } \\
\text { snd }\end{array}$ & (ECCC, 2016b) \\
\hline Hine's Emerald & Endangered & $\begin{array}{l}\text { swp } \\
\text { bog } \\
\text { fen }\end{array}$ & (ECCC, 2016b) \\
\hline Hoary Mountain-mint & Endangered & $\operatorname{tgs}$ & (ECCC, 2016b) \\
\hline Hoptree Borer & Endangered & shr & (Harris, 2018) \\
\hline Horned Grebe (Western population) & Special Concern & $\begin{array}{l}\text { msh } \\
\text { swp }\end{array}$ & (ECCC, 2016b) \\
\hline Houghton's Goldenrod & Threatened & $\begin{array}{l}\text { snd } \\
\text { shr } \\
\text { alv }\end{array}$ & (ECCC, 2016b) \\
\hline Jefferson Salamander & Endangered & dtr & (ECCC, 2016b) \\
\hline Juniper Sedge & Endangered & $\begin{array}{l}\text { alv } \\
\text { tgs } \\
\text { str }\end{array}$ & (ECCC, 2016b) \\
\hline Kentucky Coffee-tree & Threatened & $\begin{array}{c}\mathrm{msh} \\
\mathrm{str}\end{array}$ & (ECCC, 2016b) \\
\hline King Rail & Endangered & $\begin{array}{c}\mathrm{msh} \\
\mathrm{shr}\end{array}$ & (ECCC, 2016b) \\
\hline Kirtland's Warbler & Endangered & $\begin{array}{l}\mathrm{ctr} \\
\mathrm{mtr}\end{array}$ & (ECCC, 2016b) \\
\hline Lake Erie Watersnake & Special Concern & shr & $\begin{array}{l}\text { (Willson \& } \\
\text { Cunnington, 2015) }\end{array}$ \\
\hline Lake Huron Grasshopper & Threatened & $\begin{array}{l}\text { shr } \\
\text { snd }\end{array}$ & (Jones, 2018) \\
\hline Lakeside Daisy & Threatened & $\begin{array}{l}\text { tgp } \\
\text { tgs } \\
\text { alv }\end{array}$ & (ECCC, 2016b) \\
\hline Large Whorled Pogonia & Endangered & $\begin{array}{l}\mathrm{mtr} \\
\mathrm{dtr}\end{array}$ & (ECCC, 2016b) \\
\hline Laura's Clubtail & Endangered & $\begin{array}{l}\mathrm{mtr} \\
\mathrm{dtr} \\
\mathrm{ctr}\end{array}$ & (ECCC, 2016b) \\
\hline Least Bittern & Threatened & $\begin{array}{l}\text { msh } \\
\text { fen } \\
\text { bog } \\
\text { swp }\end{array}$ & (ECCC, 2016b) \\
\hline Little Brown Myotis & Endangered & $\begin{array}{c}\text { com } \\
\text { clf } \\
\text { sgm } \\
\text { tgw } \\
\text { ctr } \\
\mathrm{dtr} \\
\mathrm{mtr} \\
\mathrm{str} \\
\end{array}$ & (COSEWIC, 2013) \\
\hline
\end{tabular}




\begin{tabular}{|c|c|c|c|}
\hline & & tru & \\
\hline Loggerhead Shrike Eastern subspecies & Endangered & $\begin{array}{l}\text { alv } \\
\text { tgp } \\
\text { tgs } \\
\text { tgw } \\
\text { agr }\end{array}$ & (ECCC, 2016b) \\
\hline Loggerhead Shrike migrans subspecies & Endangered & $\begin{array}{l}\text { alv } \\
\text { tgp } \\
\text { tgs } \\
\text { tgw } \\
\text { agr }\end{array}$ & (ECCC, 2016b) \\
\hline Louisiana Waterthrush & Threatened & $\begin{array}{l}\text { ctr } \\
\text { dtr } \\
\text { mtr } \\
\text { tgw } \\
\text { tru }\end{array}$ & (ECCC, 2016b) \\
\hline Massasauga (Carolinian population) & Endangered & $\begin{array}{l}\text { tgp } \\
\text { tgw } \\
\text { bog } \\
\mathrm{msh} \\
\mathrm{shr} \\
\mathrm{alv} \\
\mathrm{dtr} \\
\mathrm{ctr} \\
\mathrm{mtr} \\
\mathrm{str}\end{array}$ & (ECCC, 2016b) \\
\hline Massasauga (Great Lakes population) & Threatened & $\begin{array}{l}\text { tgp } \\
\text { tgw } \\
\text { bog } \\
\text { msh } \\
\text { shr } \\
\text { alv } \\
\text { dtr } \\
\text { ctr } \\
\text { mtr } \\
\text { str }\end{array}$ & (ECCC, 2016b) \\
\hline Monarch & Special Concern & $\begin{array}{l}\operatorname{tgp} \\
\text { str } \\
\text { tgs } \\
\text { agr }\end{array}$ & (ECCC, 2016b) \\
\hline Mottled Duskywing (Boreal population) & Endangered & $\begin{array}{l}\text { alv } \\
\text { tgp } \\
\text { tgs } \\
\text { snd } \\
\text { str }\end{array}$ & (ECCC, 2016b) \\
\hline $\begin{array}{l}\text { Mottled Duskywing (Great Lakes Plains } \\
\text { population) }\end{array}$ & Endangered & $\begin{array}{l}\text { alv } \\
\text { tgp } \\
\text { tgs } \\
\text { snd } \\
\text { str } \\
\end{array}$ & (ECCC, 2016b) \\
\hline Nine-spotted Lady Beetle & Endangered & $\begin{array}{l}\text { agr } \\
\text { com } \\
\mathrm{mtr} \\
\mathrm{ctr} \\
\mathrm{dtr} \\
\mathrm{str} \\
\text { tru } \\
\text { tgp } \\
\text { tgs } \\
\text { tgw } \\
\text { mud } \\
\text { fen }\end{array}$ & $\begin{array}{l}\text { (Linton \& } \\
\text { McCorquodale, } \\
\text { 2018) }\end{array}$ \\
\hline Nodding Pogonia & Endangered & $\mathrm{dtr}$ & (ECCC, 2016b) \\
\hline Northern Barrens Tiger Beetle & Endangered & tgs & (ECCC, 2016b) \\
\hline
\end{tabular}




\begin{tabular}{|c|c|c|c|}
\hline & & $\begin{array}{l}\text { tgw } \\
\text { ctr } \\
\mathrm{mtr}\end{array}$ & \\
\hline Northern Bobwhite & Endangered & $\begin{array}{l}\text { tgp } \\
\text { tgs } \\
\text { tgw } \\
\text { agr }\end{array}$ & (ECCC, 2016b) \\
\hline $\begin{array}{l}\text { Northern Dusky Salamander (Carolinian } \\
\text { population) }\end{array}$ & Endangered & $\begin{array}{l}\text { dtr } \\
\text { ctr } \\
\mathrm{mtr}\end{array}$ & (ECCC, 2016b) \\
\hline Northern Myotis & Endangered & $\begin{array}{c}\text { clf } \\
\text { sgm } \\
\text { ctr } \\
\mathrm{dtr} \\
\mathrm{mtr} \\
\mathrm{str} \\
\text { tru }\end{array}$ & (COSEWIC, 2013) \\
\hline Olive-sided Flycatcher & Special Concern & $\begin{array}{l}\text { mtr } \\
\text { ctr } \\
\text { msh } \\
\text { fen } \\
\text { bog } \\
\text { swp }\end{array}$ & (ECCC, 2016b) \\
\hline Pale-bellied Frost Lichen & Endangered & $\begin{array}{l}\mathrm{mtr} \\
\mathrm{dtr} \\
\mathrm{tru} \\
\mathrm{str} \\
\mathrm{pla}\end{array}$ & (ECCC, 2016b) \\
\hline Peregrine Falcon anatum/tundrius & Special Concern & $\begin{array}{c}\text { com } \\
\text { clf }\end{array}$ & (ECCC, 2016b) \\
\hline Pink Milkwort & Endangered & $\begin{array}{l}\text { tgp } \\
\text { tgs } \\
\text { tgw } \\
\text { snd }\end{array}$ & (ECCC, 2016b) \\
\hline Piping Plover circumcinctus subspecies & Endangered & $\begin{array}{l}\text { snd } \\
\text { shr }\end{array}$ & (ECCC, 2016b) \\
\hline Pitcher's Thistle & Threatened & $\begin{array}{l}\text { shr } \\
\text { snd }\end{array}$ & (ECCC, 2016b) \\
\hline Polar Bear & Threatened & shr & (ECCC, 2016b) \\
\hline Prothonotary Warbler & Endangered & $\begin{array}{l}\text { swp } \\
\text { msh } \\
\text { dtr }\end{array}$ & (ECCC, 2016b) \\
\hline Proud Globelet & Endangered & $\begin{array}{l}\mathrm{mtr} \\
\mathrm{ctr} \\
\mathrm{dtr} \\
\mathrm{tgw} \\
\mathrm{tru}\end{array}$ & $\begin{array}{l}\text { (Wyshynski \& } \\
\text { Nicolai, 2018) }\end{array}$ \\
\hline Purple Twayblade & Threatened & $\begin{array}{c}\text { tgw } \\
\text { tgs } \\
\mathrm{mtr} \\
\mathrm{dtr} \\
\text { alv } \\
\mathrm{msh} \\
\text { swp } \\
\text { pla }\end{array}$ & (ECCC, 2016b) \\
\hline Pygmy Snaketail & Endangered & $\begin{array}{l}\mathrm{dtr} \\
\mathrm{ctr} \\
\mathrm{mtr}\end{array}$ & (ECCC, 2016b) \\
\hline Rapids Clubtail & Endangered & $\begin{array}{l}\mathrm{dtr} \\
\mathrm{ctr} \\
\mathrm{mtr}\end{array}$ & (ECCC, 2016b) \\
\hline Red Knot rufa subspecies & Endangered & $\begin{array}{l}\text { mud } \\
\text { shr }\end{array}$ & (ECCC, 2016b) \\
\hline Red Mulberry & Endangered & dtr & (ECCC, 2016b) \\
\hline
\end{tabular}




\begin{tabular}{|c|c|c|c|}
\hline & & $\begin{array}{l}\text { ctr } \\
\text { mtr } \\
\text { str } \\
\text { alv }\end{array}$ & \\
\hline Red-headed Woodpecker & Special Concern & $\begin{array}{l}\mathrm{dtr} \\
\mathrm{ctr} \\
\mathrm{mtr} \\
\mathrm{str} \\
\text { tgw } \\
\mathrm{com}\end{array}$ & (ECCC, 2016b) \\
\hline Red-necked Phalarope & Special Concern & msh & (ECCC, 2016b) \\
\hline Riddell's Goldenrod & Special Concern & $\operatorname{tgp}$ & (ECCC, 2016b) \\
\hline $\begin{array}{l}\text { Riverine Clubtail (Great Lakes Plains } \\
\text { population) }\end{array}$ & Endangered & $\begin{array}{l}\mathrm{ctr} \\
\mathrm{mtr} \\
\mathrm{dtr}\end{array}$ & (ECCC, 2016b) \\
\hline $\begin{array}{l}\text { Round-leaved Greenbrier (Great Lakes } \\
\text { Plains population) }\end{array}$ & Threatened & $\begin{array}{l}\mathrm{dtr} \\
\mathrm{str} \\
\mathrm{mtr} \\
\mathrm{msh}\end{array}$ & (ECCC, 2016b) \\
\hline Rusty Blackbird & Special Concern & $\begin{array}{l}\text { crt } \\
\text { msh } \\
\text { bog } \\
\text { fen } \\
\text { swp } \\
\text { agr }\end{array}$ & (ECCC, 2016b) \\
\hline Rusty-patched Bumble Bee & Endangered & $\begin{array}{c}\text { agr } \\
\text { com } \\
\text { tgs } \\
\text { str } \\
\text { tgw } \\
\text { snd } \\
\text { tgp }\end{array}$ & (ECCC, 2016b) \\
\hline Scarlet Ammannia & Endangered & $\begin{array}{l}\text { mud } \\
\text { swp } \\
\text { msh } \\
\text { shr }\end{array}$ & (ECCC, 2016b) \\
\hline Short-eared Owl & Special Concern & $\begin{array}{c}\text { tgp } \\
\text { tgs } \\
\text { msh } \\
\text { alv } \\
\text { het } \\
\text { agr }\end{array}$ & (ECCC, 2016b) \\
\hline Showy Goldenrod (Boreal population) & Threatened & $\begin{array}{l}\text { tgp } \\
\text { tgs } \\
\end{array}$ & (ECCC, 2016b) \\
\hline $\begin{array}{l}\text { Showy Goldenrod (Great Lake } \\
\text { population) }\end{array}$ & Endangered & $\begin{array}{l}\text { tgp } \\
\text { tgs }\end{array}$ & (ECCC, 2016b) \\
\hline Shumard Oak & Special Concern & $\begin{array}{l}\text { dtr } \\
\text { swp } \\
\text { hed }\end{array}$ & $\begin{array}{l}\text { (Donley et al., } \\
\text { 2013b) }\end{array}$ \\
\hline Skinner's Agalinis & Endangered & $\operatorname{tgp}$ & (ECCC, 2016b) \\
\hline Slender Bush-clover & Endangered & tgp & (ECCC, 2016b) \\
\hline Small White Lady's-slipper & Endangered & $\begin{array}{l}\text { fen } \\
\text { tgp } \\
\text { tgs }\end{array}$ & (ECCC, 2016b) \\
\hline Small Whorled Pogonia & Endangered & $\begin{array}{l}\mathrm{dtr} \\
\mathrm{mtr} \\
\mathrm{ctr}\end{array}$ & (ECCC, 2016b) \\
\hline Small-flowered Lipocarpha & Threatened & $\begin{array}{l}\text { shr } \\
\text { mud }\end{array}$ & (ECCC, 2016b) \\
\hline Small-mouthed Salamander & Endangered & $\begin{array}{l}\mathrm{mtr} \\
\mathrm{dtr} \\
\mathrm{agr}\end{array}$ & (ECCC, 2016b) \\
\hline
\end{tabular}




\begin{tabular}{|c|c|c|c|}
\hline & & $\operatorname{tgp}$ & \\
\hline Snapping Turtle & Special Concern & $\begin{array}{l}\text { snd } \\
\text { sgm } \\
\text { agr }\end{array}$ & (ECCC, 2016b) \\
\hline Spoon-leaved Moss & Endangered & $\begin{array}{l}\text { dtr } \\
\text { het } \\
\text { swp } \\
\text { msh } \\
\text { tgp }\end{array}$ & (ECCC, 2016b) \\
\hline Spotted Turtle & Endangered & $\begin{array}{l}\text { msh } \\
\text { bog } \\
\text { swp }\end{array}$ & (ECCC, 2016b) \\
\hline Spotted Wintergreen & Threatened & $\begin{array}{l}\mathrm{dtr} \\
\mathrm{mtr} \\
\mathrm{ctr} \\
\mathrm{tgw}\end{array}$ & (ECCC, 2016b) \\
\hline Swamp Rose-mallow & Special Concern & $\begin{array}{l}\text { fen } \\
\text { msh } \\
\text { bog } \\
\text { shr }\end{array}$ & (ECCC, 2016b) \\
\hline Toothcup & Endangered & shr & (ECCC, 2016b) \\
\hline Transverse Lady Beetle & Endangered & $\begin{array}{c}\text { agr } \\
\text { com } \\
\mathrm{mtr} \\
\mathrm{ctr} \\
\mathrm{dtr} \\
\mathrm{str} \\
\mathrm{tru} \\
\mathrm{tgp} \\
\mathrm{tgs} \\
\mathrm{tgw} \\
\text { mud } \\
\text { fen }\end{array}$ & $\begin{array}{l}\text { (Linton \& } \\
\text { McCorquodale, } \\
\text { 2019) }\end{array}$ \\
\hline Tri-coloured Bat & Endangered & $\begin{array}{c}\text { com } \\
\text { clf } \\
\text { sgm } \\
\text { tgw } \\
\text { ctr } \\
\mathrm{dtr} \\
\mathrm{mtr} \\
\mathrm{str} \\
\text { tru } \\
\mathrm{agr}\end{array}$ & (COSEWIC, 2013) \\
\hline Tuberous Indian-plantain & Special Concern & $\begin{array}{l}\text { shr } \\
\text { fen } \\
\text { msh } \\
\text { swp } \\
\text { agr } \\
\text { tgp }\end{array}$ & (ECCC, 2016b) \\
\hline Unisexual Ambystoma (Jefferson) & Endangered & $\begin{array}{l}\mathrm{mtr} \\
\mathrm{dtr}\end{array}$ & (Linton et al., 2018) \\
\hline Unisexual Ambystoma (Small-mouthed) & Endangered & $\begin{array}{l}\mathrm{mtr} \\
\mathrm{dtr}\end{array}$ & (Hossie, 2018) \\
\hline Virginia Goat's-rue & Endangered & $\begin{array}{l}\text { str } \\
\text { ctr } \\
\text { tgp } \\
\text { tgs } \\
\text { snd }\end{array}$ & (ECCC, 2016b) \\
\hline Virginia Mallow & Endangered & $\begin{array}{c}\text { shr } \\
\mathrm{msh} \\
\text { alv }\end{array}$ & (ECCC, 2016b) \\
\hline West VIrginia White & Special Concern & $\begin{array}{l}\text { dtr } \\
\text { pla }\end{array}$ & (Burke, 2013) \\
\hline Western Silvery Aster & Endangered & $\operatorname{tgs}$ & (ECCC, 2016b) \\
\hline
\end{tabular}




\begin{tabular}{|c|c|c|c|}
\hline White Prairie Gentian & Endangered & $\begin{array}{l}\text { tgw } \\
\text { tgs }\end{array}$ & (ECCC, 2016b) \\
\hline White Wood Aster & Threatened & $\begin{array}{l}\text { str } \\
\text { dtr } \\
\text { tru }\end{array}$ & (ECCC, 2016b) \\
\hline Wild Hyacinth & Threatened & $\begin{array}{l}\text { str } \\
\text { tgw } \\
\text { het }\end{array}$ & (ECCC, 2016b) \\
\hline Willowleaf Aster & Threatened & tgs & (ECCC, 2016b) \\
\hline Wolverine & Threatened & $\begin{array}{l}\text { dtr } \\
\text { mtr } \\
\text { ctr } \\
\text { str } \\
\text { het } \\
\text { tru }\end{array}$ & (ECCC, 2016b) \\
\hline Wood Thrush & Special Concern & $\begin{array}{l}\mathrm{mtr} \\
\mathrm{dtr}\end{array}$ & (ECCC, 2016b) \\
\hline Wood Turtle & Endangered & $\begin{array}{c}\text { str } \\
\mathrm{mtr} \\
\mathrm{ctr} \\
\mathrm{dtr} \\
\mathrm{tgp} \\
\text { swp } \\
\text { agr } \\
\text { fen }\end{array}$ & (ECCC, 2016b) \\
\hline Woodland Caribou (Boreal population) & Threatened & $\begin{array}{l}\text { str } \\
\text { tru } \\
\mathrm{mtr}\end{array}$ & (ECCC, 2016b) \\
\hline Woodland Vole & Special Concern & $\mathrm{dtr}$ & (ECCC, 2016b) \\
\hline Wood-poppy & Endangered & $\begin{array}{l}\mathrm{mtr} \\
\mathrm{dtr}\end{array}$ & (ECCC, 2016b) \\
\hline Yellow Rail & Special Concern & $\begin{array}{l}\text { msh } \\
\text { fen } \\
\text { bog } \\
\text { tgp }\end{array}$ & (ECCC, 2016b) \\
\hline Yellow-banded Bumble Bee & Special Concern & $\begin{array}{c}\text { str } \\
\mathrm{mtr} \\
\mathrm{ctr} \\
\mathrm{dtr} \\
\mathrm{tru} \\
\mathrm{tgw} \\
\mathrm{tgp} \\
\mathrm{tgs} \\
\text { agr } \\
\text { fen } \\
\text { com }\end{array}$ & (OMECP, 2019c) \\
\hline Yellow-breasted Chat virens subspecies & Endangered & $\begin{array}{l}\text { msh } \\
\text { het } \\
\text { tgp } \\
\text { tgs } \\
\text { agr } \\
\text { fen }\end{array}$ & (ECCC, 2016b) \\
\hline
\end{tabular}

*Abbreviations: agr = agriculture/rural; alv = alvar; bdr = bedrock; bog = bog; $c l f=$ cliffs and talus; com = community/infrastructure; $\mathrm{ctr}=$ coniferous treed; $\mathrm{dtr}=$ deciduous treed; fen = fen; hed = hedge row; het = heath; $\mathrm{msh}=$ marsh; $\mathrm{mtr}=$ mixed treed; mud = mudflats; $\mathrm{pla}=$ plantation, $\mathrm{sgm}=$ sand, gravel, mine; $\mathrm{shr}=$ shoreline; snd $=$ sand barren/dune; $\operatorname{str}=$ sparse treed; swp $=$ swamp; $\operatorname{tgp}=$ open trallgrass prairie; $\operatorname{tgs}=$ tallgrass savannah; $\operatorname{tgw}=$ tallgrass woodland; tru = treed upland. 
Table A2. Percent protected habitat and percent habitat on Crown land for each species on the Species at Risk in Ontario List

\begin{tabular}{|c|c|c|}
\hline Species & $\begin{array}{l}\text { Protected } \\
\text { Habitat (\%) }\end{array}$ & $\begin{array}{l}\text { Habitat on } \\
\text { Crown Land (\%) }\end{array}$ \\
\hline Acadian Flycatcher & 6.3 & 4.0 \\
\hline Algonquin Wolf & 26.9 & 67.9 \\
\hline $\begin{array}{l}\text { Allegheny Mountain Dusky Salamander (Carolinian } \\
\text { population) }\end{array}$ & 6.2 & 0.0 \\
\hline $\begin{array}{l}\text { Allegheny Mountain Dusky Salamander (Great Lakes / } \\
\text { St. Lawrence population) }\end{array}$ & 1.2 & 0.0 \\
\hline American Badger jacksoni subspecies & 1.4 & 1.7 \\
\hline $\begin{array}{l}\text { American Badger jeffersonii subspecies (Eastern } \\
\text { population) }\end{array}$ & 2.2 & 0.0 \\
\hline American Chestnut & 6.8 & 0.1 \\
\hline American Columbo & 2.5 & 0.0 \\
\hline American Ginseng & 4.5 & 18.4 \\
\hline American Water-willow & 74.9 & 6.8 \\
\hline American White Pelican & 11.7 & 88.4 \\
\hline Aweme Borer & 60.4 & 6.5 \\
\hline Bald Eagle & 6.3 & 33.1 \\
\hline Bank Swallow & 1.2 & 14.7 \\
\hline Barn Owl (Eastern population) & 2.0 & 0.0 \\
\hline Barn Swallow & 1.2 & 14.4 \\
\hline Bashful Bulrush & 0.0 & 0.0 \\
\hline Bent Spike-rush (Great Lakes Plains population) & 93.3 & 0.0 \\
\hline Bird's-foot Violet & 0.0 & 0.0 \\
\hline Black Tern & 3.4 & 26.6 \\
\hline $\begin{array}{l}\text { Blanding's Turtle (Great Lakes / St. Lawrence } \\
\text { population) }\end{array}$ & 6.2 & 23.8 \\
\hline Blue Ash & 8.2 & 0.0 \\
\hline Blue Racer & 2.5 & 0.0 \\
\hline Bluehearts & 55.2 & 7.5 \\
\hline Blunt-lobed Woodsia & 14.2 & 0.0 \\
\hline Bobolink & 0.9 & 10.9 \\
\hline Bogbean Buckmoth & 0.0 & 68.0 \\
\hline Branched Bartonia & 14.5 & 85.6 \\
\hline Broad-banded Forestsnail & 23.7 & 0.0 \\
\hline Butler's Gartersnake & 4.1 & 0.0 \\
\hline Butternut & 5.7 & 43.4 \\
\hline Canada Warbler & 13.4 & 68.3 \\
\hline Caribou (Eastern Migratory) & 14.6 & 0.4 \\
\hline Cerulean Warbler & 7.9 & 14.0 \\
\hline Cherry Birch & 0.0 & 0.0 \\
\hline Chimney Swift & 1.6 & 17.0 \\
\hline
\end{tabular}




\begin{tabular}{|c|c|c|}
\hline Climbing Prairie Rose & 3.0 & 0.0 \\
\hline Colicroot & 13.6 & 0.0 \\
\hline Common Hoptree & 52.7 & 0.0 \\
\hline Common Nighthawk & 6.8 & 33.6 \\
\hline Crooked-stem Aster & 0.0 & 0.0 \\
\hline Cucumber Tree & 11.0 & 0.1 \\
\hline Deerberry & 6.2 & 0.0 \\
\hline Dense Blazing Star & 5.8 & 0.0 \\
\hline Drooping Trillium & 0.0 & 0.0 \\
\hline Dwarf Hackberry & 50.1 & 4.6 \\
\hline Dwarf Lake Iris & 29.9 & 16.9 \\
\hline Eastern Banded Tigersnail & 41.2 & 0.0 \\
\hline Eastern Flowering Dogwood & 5.7 & 0.0 \\
\hline Eastern Foxsnake (Carolinian population) & 3.9 & 0.0 \\
\hline $\begin{array}{l}\text { Eastern Foxsnake (Great Lakes / St. Lawrence } \\
\text { population) }\end{array}$ & 49.2 & 41.8 \\
\hline Eastern Hog-nosed Snake & 13.0 & 47.0 \\
\hline Eastern Meadowlark & 1.0 & 10.2 \\
\hline Eastern Mole & 0.9 & 0.0 \\
\hline Eastern Musk Turtle & 4.2 & 16.9 \\
\hline Eastern Prairie Fringed-orchid & 4.8 & 3.8 \\
\hline Eastern Prickly Pear Cactus & 92.7 & 0.0 \\
\hline Eastern Ribbonsnake (Great Lakes population) & 4.2 & 19.8 \\
\hline Eastern Small-footed Myotis & 15.4 & 72.3 \\
\hline Eastern Whip-poor-will & 11.5 & 53.3 \\
\hline Eastern Wood-pewee & 14.1 & 79.7 \\
\hline Evening Grosbeak & 6.7 & 35.9 \\
\hline False Hop Sedge & 0.7 & 0.0 \\
\hline False Rue-anemone & 0.8 & 0.0 \\
\hline Five-lined Skink (Carolinian population) & 84.8 & 6.2 \\
\hline $\begin{array}{l}\text { Five-lined Skink (Great Lakes / St. Lawrence } \\
\text { population) }\end{array}$ & 39.6 & 60.8 \\
\hline Forked Three-awned Grass & 1.1 & 0.0 \\
\hline Four-leaved Milkweed & 2.9 & 0.0 \\
\hline Fowler's Toad & 45.5 & 2.5 \\
\hline Gattinger's Agalinis & 97.0 & 0.0 \\
\hline Golden Eagle & 9.0 & 66.1 \\
\hline Golden-eyed Lichen & 95.9 & 0.0 \\
\hline Goldenseal & 22.7 & 0.0 \\
\hline Golden-winged Warbler & 4.2 & 20.8 \\
\hline Grasshopper Sparrow, pratensis subspecies & 1.2 & 8.0 \\
\hline Gray Fox & 8.8 & 34.7 \\
\hline Gray Ratsnake (Carolinian population) & 3.2 & 0.0 \\
\hline
\end{tabular}




\begin{tabular}{|c|c|c|}
\hline Gray Ratsnake (Great Lakes / St. Lawrence population) & 2.5 & 7.8 \\
\hline Green Dragon & 4.9 & 0.0 \\
\hline Gypsy Cuckoo Bumble Bee & 11.4 & 58.0 \\
\hline Hart's-tongue Fern & 6.3 & 0.0 \\
\hline Heart-leaved Plantain & 3.0 & 0.0 \\
\hline Henslow's Sparrow & 1.9 & 2.9 \\
\hline Hill's Thistle & 70.8 & 0.0 \\
\hline Hine's Emerald & 6.5 & 0.0 \\
\hline Hoary Mountain-mint & 0.0 & 0.0 \\
\hline Hoptree Borer & 88.6 & 0.0 \\
\hline Horned Grebe (Western population) & 10.9 & 6.3 \\
\hline Houghton's Goldenrod & 52.2 & 0.0 \\
\hline Jefferson Salamander & 7.6 & 0.0 \\
\hline Juniper Sedge & 17.3 & 0.0 \\
\hline Kentucky Coffee-tree & 91.6 & 0.0 \\
\hline King Rail & 34.3 & 0.3 \\
\hline Kirtland's Warbler & 45.0 & 31.9 \\
\hline Lake Erie Watersnake & 0.0 & 0.0 \\
\hline Lake Huron Grasshopper & 0.0 & 0.0 \\
\hline Lakeside Daisy & 100.0 & 0.0 \\
\hline Large Whorled Pogonia & 0.0 & 0.0 \\
\hline Laura's Clubtail & 4.9 & 0.0 \\
\hline Least Bittern & 6.8 & 22.8 \\
\hline Little Brown Myotis & 13.2 & 71.3 \\
\hline Loggerhead Shrike Eastern subspecies & 1.5 & 22.1 \\
\hline Loggerhead Shrike migrans subspecies & 1.4 & 21.7 \\
\hline Louisiana Waterthrush & 5.6 & 32.1 \\
\hline Massasauga (Carolinian population) & 12.4 & 0.0 \\
\hline Massasauga (Great Lakes population) & 21.6 & 62.7 \\
\hline Monarch & 5.4 & 40.0 \\
\hline Mottled Duskywing (Boreal population) & 93.3 & 6.7 \\
\hline Mottled Duskywing (Great Lakes Plains population) & 21.8 & 51.8 \\
\hline Nine-spotted Lady Beetle & 11.7 & 37.8 \\
\hline Nodding Pogonia & 16.9 & 0.0 \\
\hline Northern Barrens Tiger Beetle & 54.8 & 3.4 \\
\hline Northern Bobwhite & 1.6 & 0.0 \\
\hline Northern Dusky Salamander (Carolinian population) & 0.0 & 0.0 \\
\hline Northern Myotis & 13.6 & 72.2 \\
\hline Olive-sided Flycatcher & 8.6 & 39.3 \\
\hline Pale-bellied Frost Lichen & 1.6 & 65.8 \\
\hline Peregrine Falcon anatum/tundrius & 1.3 & 20.5 \\
\hline Pink Milkwort & 61.3 & 0.0 \\
\hline Piping Plover circumcinctus subspecies & 92.6 & 0.0 \\
\hline
\end{tabular}




\begin{tabular}{|c|c|c|}
\hline Pitcher's Thistle & 98.8 & 19.0 \\
\hline Polar Bear & 0.0 & 0.0 \\
\hline Prothonotary Warbler & 10.7 & 0.4 \\
\hline Proud Globelet & 0.0 & 0.0 \\
\hline Purple Twayblade & 5.4 & 0.0 \\
\hline Pygmy Snaketail & 22.2 & 77.8 \\
\hline Rapids Clubtail & 2.6 & 54.6 \\
\hline Red Knot rufa subspecies & 79.3 & 33.6 \\
\hline Red Mulberry & 4.8 & 0.0 \\
\hline Red-headed Woodpecker & 15.3 & 73.6 \\
\hline Red-necked Phalarope & 67.1 & 14.3 \\
\hline Riddell's Goldenrod & 94.2 & 0.0 \\
\hline Riverine Clubtail (Great Lakes Plains population) & 5.3 & 0.0 \\
\hline $\begin{array}{l}\text { Round-leaved Greenbrier (Great Lakes Plains } \\
\text { population) }\end{array}$ & 11.6 & 0.0 \\
\hline Rusty Blackbird & 8.2 & 17.2 \\
\hline Rusty-patched Bumble Bee & 1.6 & 8.9 \\
\hline Scarlet Ammannia & 32.9 & 0.0 \\
\hline Short-eared Owl & 2.6 & 12.4 \\
\hline Showy Goldenrod (Boreal population) & 0.0 & 0.0 \\
\hline Showy Goldenrod (Great Lake population) & 94.3 & 0.0 \\
\hline Shumard Oak & 5.5 & 0.2 \\
\hline Skinner's Agalinis & 99.1 & 0.0 \\
\hline Slender Bush-clover & 0.0 & 0.0 \\
\hline Small White Lady's-slipper & 97.1 & 2.9 \\
\hline Small Whorled Pogonia & 0.0 & 0.0 \\
\hline Small-flowered Lipocarpha & 0.0 & 0.0 \\
\hline Small-mouthed Salamander & 12.9 & 0.0 \\
\hline Snapping Turtle & 1.2 & 10.9 \\
\hline Spoon-leaved Moss & 0.6 & 0.0 \\
\hline Spotted Turtle & 3.8 & 12.9 \\
\hline Spotted Wintergreen & 27.2 & 0.0 \\
\hline Swamp Rose-mallow & 67.5 & 0.3 \\
\hline Toothcup & 0.0 & 0.0 \\
\hline Transverse Lady Beetle & 9.8 & 50.9 \\
\hline Tri-coloured Bat & 10.5 & 61.1 \\
\hline Tuberous Indian-plantain & 4.2 & 0.0 \\
\hline Unisexual Ambystoma (Jefferson) & 6.9 & 0.0 \\
\hline Unisexual Ambystoma (Small-mouthed) & 39.4 & 0.0 \\
\hline Virginia Goat's-rue & 64.4 & 0.0 \\
\hline Virginia Mallow & 0.0 & 0.0 \\
\hline West VIrginia White & 15.8 & 57.9 \\
\hline Western Silvery Aster & 0.0 & 0.0 \\
\hline
\end{tabular}




\begin{tabular}{|l|r|r|}
\hline White Prairie Gentian & 100.0 & 0.0 \\
\hline White Wood Aster & 3.7 & 0.0 \\
\hline Wild Hyacinth & 0.0 & 0.0 \\
\hline Willowleaf Aster & 56.1 & 0.0 \\
\hline Wolverine & 9.2 & 20.1 \\
\hline Wood Thrush & 14.8 & 78.9 \\
\hline Wood Turtle & 25.7 & 67.7 \\
\hline Woodland Caribou (Boreal population) & 12.4 & 56.5 \\
\hline Woodland Vole & 7.1 & 0.0 \\
\hline Wood-poppy & 0.0 & 0.0 \\
\hline Yellow Rail & 27.4 & 13.8 \\
\hline Yellow-banded Bumble Bee & & 58.5 \\
\hline Yellow-breasted Chat virens subspecies & 1.3 & 0.7 \\
\hline
\end{tabular}

Table A3. Total price, area, and number of parcels prioritized in each protection scenario

\begin{tabular}{|c|r|r|r|}
\hline $\begin{array}{c}\text { Habitat } \\
\text { Protected (\%) }\end{array}$ & Total Parcels & Total Area (ha) & $\begin{array}{r}\text { Total Price } \\
\text { (10 } \mathbf{6} \text { CAD) }\end{array}$ \\
\hline $\mathbf{5}$ & 13,292 & 97,479 & 6.3 \\
\hline $\mathbf{1 0}$ & 61,101 & 489,223 & 838 \\
\hline $\mathbf{2 0}$ & 100,955 & $1,339,726$ & 3,532 \\
\hline $\mathbf{3 0}$ & 135,882 & $2,326,241$ & 7,446 \\
\hline $\mathbf{4 0}$ & 187,354 & $4,087,012$ & 12,670 \\
\hline $\mathbf{5 0}$ & 225,190 & $5,339,499$ & 20,078 \\
\hline $\mathbf{6 0}$ & 299,108 & $6,508,248$ & 31,245 \\
\hline $\mathbf{7 0}$ & 451,416 & $7,987,821$ & 47,223 \\
\hline $\mathbf{8 0}$ & 584,128 & $9,529,129$ & 69,256 \\
\hline $\mathbf{9 0}$ & 805,687 & $11,605,624$ & 101,754 \\
\hline $\mathbf{1 0 0}$ & $2,438,558$ & $15,335,992$ & 302,171 \\
\hline
\end{tabular}

Table A4. Estimated land cost, total population, and population density from 2011 census for each census division

\begin{tabular}{|l|r|r|r|}
\hline \multicolumn{1}{|c|}{ Census Division } & $\begin{array}{c}\text { Cost per Hectare } \\
\text { (CAD) }\end{array}$ & $\begin{array}{r}\text { Total Population in } \\
\text { 2011 }\end{array}$ & \multicolumn{1}{c|}{$\begin{array}{c}\text { Population Density } \\
\text { (per square km) }\end{array}$} \\
\hline Algoma & 396 & 115,870 & 124 \\
\hline Brant & 58,340 & 136,035 & 16 \\
\hline Bruce & 9,848 & 66,102 & 42 \\
\hline Chatham-Kent & 33,793 & 104,075 & 1 \\
\hline Cochrane & 536 & 81,122 & 38 \\
\hline Dufferin & 21,108 & 56,881 & \\
\hline
\end{tabular}




\begin{tabular}{|c|c|c|c|}
\hline Durham & 55,657 & 608,124 & 241 \\
\hline Elgin & 29,331 & 87,461 & 46 \\
\hline Essex & 51,531 & 388,782 & 210 \\
\hline Frontenac & 7,311 & 149,738 & 40 \\
\hline Greater Sudbury & 1,917 & 160,376 & 50 \\
\hline Grey & 15,264 & 92,568 & 21 \\
\hline Haldimand-Norfolk & 23,364 & 109,118 & 38 \\
\hline Haliburton & 2,297 & 17,026 & 4 \\
\hline Halton & 198,881 & 501,669 & 520 \\
\hline Hamilton & 107,934 & 519,949 & 465 \\
\hline Hastings & 4,266 & 134,934 & 22 \\
\hline Huron & 31,557 & 59,100 & 17 \\
\hline Kawartha Lakes & 10,061 & 73,214 & 24 \\
\hline Kenora & 1,560 & 57,607 & 0 \\
\hline Lambton & 25,400 & 126,199 & 42 \\
\hline Lanark & 3,709 & 65,667 & 22 \\
\hline Leeds and Grenville & 9,443 & 99,306 & 29 \\
\hline Lennox and Addington & 5,398 & 41,824 & 15 \\
\hline Manitoulin & 1,024 & 13,048 & 4 \\
\hline Middlesex & 49,115 & 439,151 & 132 \\
\hline Muskoka & 3,395 & 58,047 & 15 \\
\hline Niagara & 55,237 & 431,346 & 233 \\
\hline Nipissing & 554 & 84,736 & 5 \\
\hline Northumberland & 19,505 & 82,126 & 43 \\
\hline Ottawa & 51,617 & 883,391 & 317 \\
\hline Oxford & 40,405 & 105,719 & 52 \\
\hline Parry Sound & 2,049 & 42,162 & 5 \\
\hline Peel & 257,092 & $1,296,814$ & 1040 \\
\hline Perth & 32,731 & 75,112 & 34 \\
\hline Peterborough & 11,800 & 134,933 & 35 \\
\hline Prescott and Russell & 18,738 & 85,381 & 43 \\
\hline Prince Edward & 16,179 & 25,258 & 24 \\
\hline Rainy River & 1,310 & 20,370 & 1 \\
\hline Renfrew & 2,225 & 101,326 & 14 \\
\hline Simcoe & 35,271 & 446,063 & 92 \\
\hline $\begin{array}{l}\text { Stormont, Dundas and } \\
\text { Glengarry }\end{array}$ & 19,440 & 111,164 & 34 \\
\hline Sudbury & 793 & 21,196 & 1 \\
\hline Thunder Bay & 616 & 146,057 & 1 \\
\hline Timiskaming & 1,494 & 32,634 & 2 \\
\hline Waterloo & 104,891 & 507,096 & 370 \\
\hline Wellington & 45,023 & 208,360 & 78 \\
\hline York & 165,620 & $1,032,524$ & 586 \\
\hline
\end{tabular}




\section{Appendix B: Supplemental Figures}

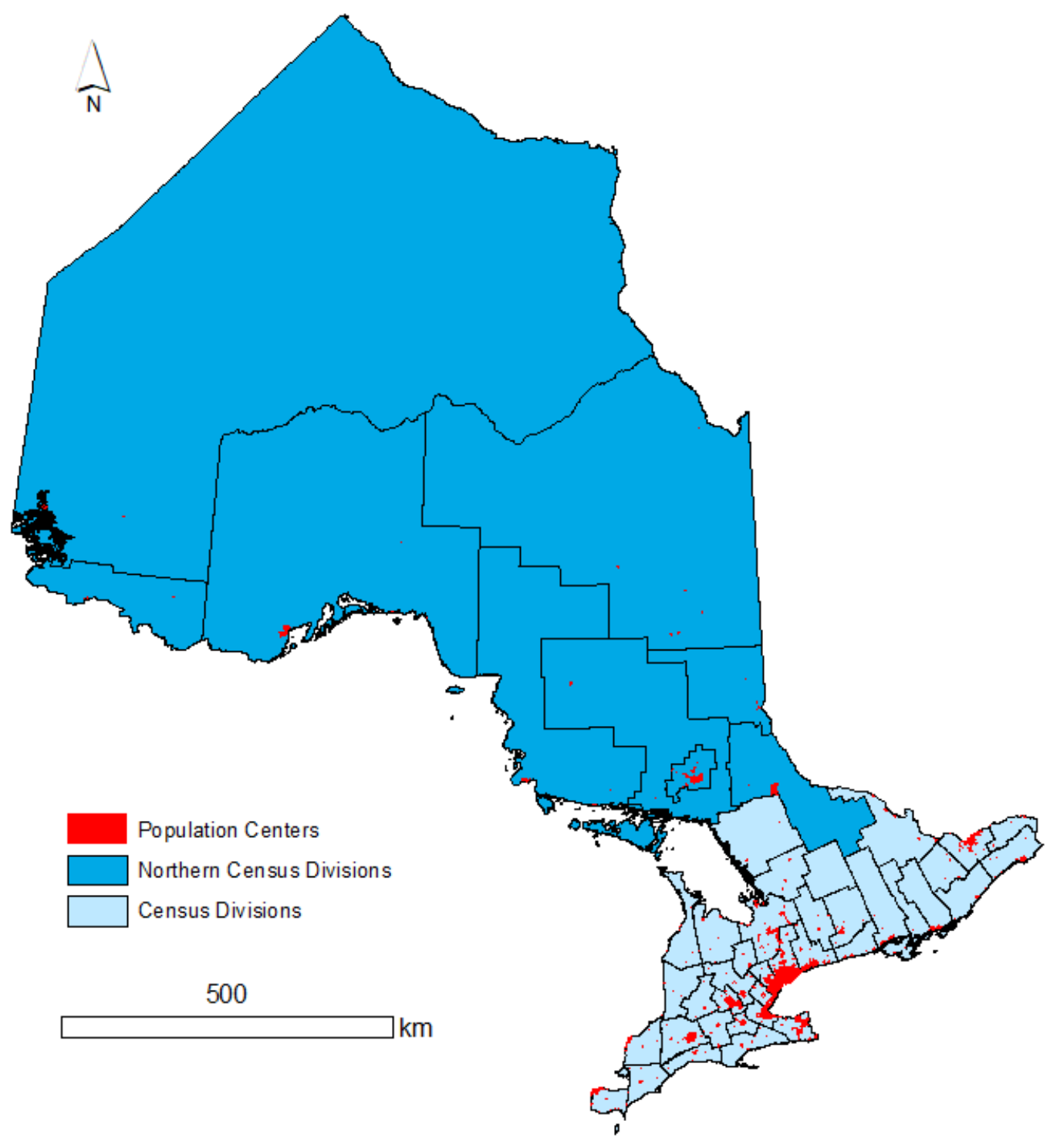

Figure B1. Northern census divisions and population centers (Statistics Canada, 2016) in Ontario 


\section{Appendix C: Model Summary}

$\operatorname{lm}($ formula $=\log ($ price $) \sim($ CDNAME $)+\log ($ Area $)+$ as.factor $($ BinWater $)+$ as.factor(BinBuild) + as.factor(BinFarm) + as.factor(BinForest), data $=$ CDdatadummy, na.action $=$ na.omit $)$

Residuals:

Min 1Q Median 3Q Max

$\begin{array}{lllll}-3.5452 & -0.3539 & 0.0155 & 0.3677 & 2.5803\end{array}$

Coefficients:

Estimate Std. Error t value $\operatorname{Pr}(>|\mathrm{t}|)$

(Intercept) $10.115350 .1349874 .941<2 \mathrm{e}-16 * * *$

CDNAMEBrant

$1.949620 .1594612 .227<2 \mathrm{e}-16 * * *$

CDNAMEBruce

CDNAMEChatham-Kent

$1.04368 \quad 0.15896 \quad 6.5666 .52 \mathrm{e}-11 * * *$

CDNAMECochrane

$1.997510 .1603312 .459<2 \mathrm{e}-16 * * *$

CDNAMEDufferin

$-0.403670 .18044-2.2370 .025378 *$

CDNAMEDurham

CDNAMEElgin

$1.68260 \quad 0.1588010 .596<2 \mathrm{e}-16 * * *$

$1.764930 .1591011 .094<2 \mathrm{e}-16 * * *$

CDNAMEEssex

CDNAMEFrontenac

$1.800480 .1595311 .286<2 \mathrm{e}-16 * * *$

CDNAMEGreater Sudbury

$1.53722 \quad 0.15898 \quad 9.669<2 \mathrm{e}-16 * * *$

$0.59794 \quad 0.15707 \quad 3.8070 .000145 * * *$

CDNAMEGrey

$0.86341 \quad 0.18179 \quad 4.7492 .18 \mathrm{e}-06 * * *$

CDNAMEHaldimand-Norfolk

$1.437770 .15858 \quad 9.067<2 \mathrm{e}-16 * * *$

CDNAMEHaliburton

CDNAMEHalton

CDNAMEHamilton

CDNAMEHastings

CDNAMEHuron

CDNAMEKawartha Lakes

CDNAMEKenora

CDNAMELambton

CDNAMELanark

$1.531030 .15913 \quad 9.621<2 \mathrm{e}-16 * * *$

$1.12552 \quad 0.15704 \quad 7.1671 .06 \mathrm{e}-12 * * *$

$2.461820 .1585515 .527<2 \mathrm{e}-16 * * *$

$1.89926 \quad 0.1597011 .893<2 \mathrm{e}-16 * * *$

$0.596390 .15746 \quad 3.7880 .000156 * * *$

$2.24650 \quad 0.15997 \quad 14.043<2 \mathrm{e}-16 * * *$

$1.149390 .15821 \quad 7.2655 .24 \mathrm{e}-13 * * *$

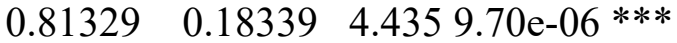

$1.809710 .16056 \quad 11.271<2 \mathrm{e}-16 * * *$

$0.80620 \quad 0.15821 \quad 5.0963 .79 \mathrm{e}-07 * * *$

CDNAMELeeds and Grenville

CDNAMELennox and Addington

CDNAMEManitoulin

$0.78018 \quad 0.15778 \quad 4.9458 .23 \mathrm{e}-07 * * *$

CDNAMEMiddlesex

CDNAMEMuskoka

CDNAMENiagara

CDNAMENipissing

CDNAMENorthumberland

$0.69191 \quad 0.15744 \quad 4.3951 .17 \mathrm{e}-05 * * *$

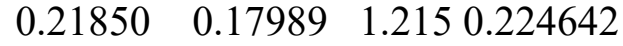

$1.980520 .15979 \quad 12.395<2 \mathrm{e}-16 * * *$

$\begin{array}{llll}1.00057 & 0.15707 & 6.370 & 2.31 \mathrm{e}-10 * * *\end{array}$

$1.445740 .15949 \quad 9.065<2 \mathrm{e}-16 * * *$

$0.64131 \quad 0.17976 \quad 3.5680 .000369 * * *$

CDNAMEOttawa

$1.25469 \quad 0.15940 \quad 7.8715 .59 \mathrm{e}-15 * * *$

CDNAMEOxford

CDNAMEParry Sound

CDNAMEPeel

$1.617920 .1583610 .217<2 \mathrm{e}-16 * * *$

$2.113890 .1593813 .263<2 \mathrm{e}-16 * * *$

$0.42516 \quad 0.15775 \quad 2.6950 .007092 * *$

$2.364060 .15881 \quad 14.886<2 \mathrm{e}-16 * * *$ 
CDNAMEPerth

CDNAMEPeterborough

CDNAMEPrescott and Russell

CDNAMEPrince Edward

CDNAMERainy River

CDNAMERenfrew

CDNAMESimcoe
$2.15307 \quad 0.16041 \quad 13.422<2 \mathrm{e}-16 * * *$

$1.14242 \quad 0.15761 \quad 7.2495 .91 \mathrm{e}-13 * * *$

$1.34080 \quad 0.158018 .486<2 \mathrm{e}-16 * * *$

$\begin{array}{lll}1.26636 & 0.15832 & 7.999 \\ 2.07 \mathrm{e}-15 * * *\end{array}$

$0.35613 \quad 0.17986 \quad 1.9800 .047829 *$

$\begin{array}{llll}0.46432 & 0.15814 & 2.9360 .003360 * *\end{array}$

$1.594710 .15788 \quad 10.101<2 \mathrm{e}-16 * * *$

$* * *$

CDNAMESudbury

CDNAMEThunder Bay

CDNAMETimiskaming

CDNAMEWaterloo

CDNAMEWellington

CDNAMEYork

$\log$ (Area)

as.factor(BinWater)1

as.factor(BinBuild)1

as.factor(BinFarm)1

as.factor(BinForest) 1
$0.44021 \quad 0.18153 \quad 2.4250 .015392 *$

$\begin{array}{llll}0.10576 & 0.18170 & 0.582 & 0.560613\end{array}$

$0.58020 \quad 0.18007 \quad 3.2220 .001292 * *$

$2.15496 \quad 0.16031 \quad 13.443<2 \mathrm{e}-16 * * *$

$2.143710 .1589513 .487<2 \mathrm{e}-16 * * *$

$2.180740 .1585213 .757<2 \mathrm{e}-16 * * *$

$0.172440 .01007 \quad 17.120<2 \mathrm{e}-16 * * *$

$0.749010 .0522214 .344<2 \mathrm{e}-16 * * *$

$0.910920 .0355025 .659<2 \mathrm{e}-16 * * *$

$0.22550 \quad 0.04041 \quad 5.5802 .71 \mathrm{e}-08 * * *$

$-0.35651 \quad 0.08431-4.2292 .45 \mathrm{e}-05 * * *$

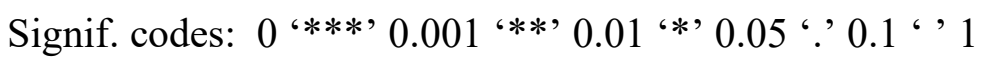

Residual standard error: 0.6216 on 2084 degrees of freedom

(13 observations deleted due to missingness)

Multiple R-squared: 0.6575, Adjusted R-squared: 0.649

F-statistic: 76.94 on 52 and 2084 DF, p-value: $<2.2 \mathrm{e}-16$ 